\title{
GAGASAN NURUDDIN AR-RANIRI DALAM 'TIBYAN FI MA'RIFAH AL-ADYAN'
}

\author{
Miswari*
}

\begin{abstract}
Abstrak
Tulisan ini hanya mengulas tentang narasi dalam 'Tibyan fi Ma'rifah Al-Adyan' karya Nuruddin Ar-Raniri. Penulis berpendapat, redaksi klasik yang disampaikan Ar-Raniri dalam kitab tersebut sulit dipahami oleh pembaca kontemporer. Untuk itu, penulis hanya berusaha merarasikan ulang pesan-pesan Ar-raniri dalam 'Tibyan fi Ma'rifah Al-Adyan'. Tulisan ini diharapkan dapat mempermudah pemahaman atas gagasan Ar-Raniri. 'Tibyan fi Ma'rifah Al-Adyan' ditulis untuk menegubkan identitas Ablus-Sunnah Waljama'ah d Aceh pada Abad ke-16. Diharapkan para peneliti atas pemikiran Ar-Raniri dapat merujukartikel ini untuk memudabkan pemahaman atas 'Tibyan fi Ma'rifah Al-Adyan'.
\end{abstract}

Kata Kunci: Tibyan fi Ma'rifah Al-Adyan, Nuruddin Ar-Raniri, Ahlus-Sunnah Waljama'ah, Wujudiyah

\section{A. PENDUAhuluan}

Nuruddin Ar-Raniri dalam pengantar 'Tibyan fi Ma'rifab Al-Adyan', mengatakan buku tersebut ditulis atas pesanan Ratu Safiatuddin setelah Iskandar Tsani mangkat. Buku itu bertujuan memperjelas sekaligus meneguhkan identitas Ahlus-sunnah Waljama'ah di tengah keberagamaan aliran dan mazhab dalam masyarakat Aceh waktu itu. Buku dimaksud disusun dalam dua bagian. Pertama adalah perbandingan agama-agama ummat manusia dan kedua adalah perbandingan aliran-aliran dalam Islam.

Di dalam karya tersebut, diuraikan kronologi kesesatan ummat manusia yang menyelewengkan ajaran para rasul. Secara perlahan, umat manusia mengarahkan perintah agama sesuai dengan tafsiran pribadi mereka. Orang-orang yang dianggap memiliki otoritas untuk menafsirkan perintah Tuhan melalui para rasul secara perlahan menjadi keliru dalam memahami agama. Sehingga penyimpangan yang terjadi di dalam

*Penulis adalah Dosen Filsafat IAIN Langsa, Email: miswari@iainlangsa.ac.id 
kehidupan ummat menjadi semakin besar. Ketika agama menjadi tergelincir dari ajaran aslinya, rasul kemudia di utus untuk memperbaiki penyimpangan itu. Demikian seterusnya hingga nabi terakhir, Muhammad Saw.

Ummat Islam juga semakin lama semakin terpecah menjadi banyak aliran. Aliran-aliran itu diulas kesesatan-kesesatannya oleh ArRaniri. Di antara aliran yang paling di tentang Ar-Raniri adalah ajaran Hamzah Fansuri dan Pengikutnya, Syamsuddin Al-Sumatrani. Ar-Raniri memberikan porsi besar untuk menunjukkan hal-hal yang dianggapnya penuh ketimpangan di dalam ajaran Wujudiyah.

\section{B. NARASI DALAM TIBYAN FI MA'RIFAH AL-ADYAN}

\section{Agama agama}

Pada bagian awal tentang perbandingan agama, Nuruddin ArRaniri mengatakan ketika Allah menzahirkan insan, maka dijadikan-Nya Adam. Di surga, Adam adalah wali Allah. Ketika diturunkan ke dunia, maka diberikan nubuwah kepadanya. Alasannya, dunia adalah wadah taklif. Maka diturunkan syariat dan taklif. Sementara surga bukan wadah taklif. Surga adalah tempat istimewa dan tempat musyahadah (Ar-Raniri, 2011: 12-13).

Sebelum beranak cucu, Adam adalah nabi. Dia mendapat petunjuk dari Allah untuk dirinya. Setelah anak cucunya ada, Adam diangkat menjadi rasul. Sehingga dia bertugas memberi petunjuk pada anak cucunya. Kata Nuruddin Ar-Raniri, Allah menurunkan suhuf kepada Adam sebagai bekal kerasulan. Maka siapa yang mengikuti suhuf itu, akan selamat imannya. Sementara bagi yang ingkar akan sesat seperti Qabil.

Setelah Adam wafat, dibuatlah sebuah patung Adam dengan tujuan mengingat ajaran Adam. Setelah generasi pembuat patung meninggal, generasi selanjutnya malah menjadikan patung Adam sebagai sesembahan, sehingga digolongkan oleh Nuruddin Ar-Raniri sebagai penyembah berhala (Ar-Raniri, 2011: 14).

Hingga masa Idris, ada lima orang yang masih menjaga iman sebagaimana diajarkan Adam. Mereka mengikuti ajaran Idris, yakni Wazad, Suwa, Yaghut, Ya'uq dan Nasar. Setelah Idris diangkat, kelima orang tersebut melanjutkan tugas menuntun ummat manusia. Setelah kelima orang itu wafat, sebagian di antara murid mereka menyarankan agar dibuat patung kelima guru mereka itu agar mereka terus mengingat ajaran kelima orang itu. Generasi pengikut lima orang itu kemudian meninggal dalam iman.

Generasi selanjutnya disesatkan setan. Mereka malah menjadikan lima patung tadi sebagai Tuhan. Mereka membangun kembali lima patung 
itu yang semula dari batu dengan emas, perak dan tembaga. Mereka menyembah patung-patung itu dalam kekafiran hingga Nabi Nuh menyeru untuk kembali menyembah Allah. Namun mereka ingkar pada ajakan Nuh. Sehingga Nuh berdoa agar orang yang tidak menyembah Allah dibinasakan. Maka datanglah banjir yang memusnahkan semua yang kafir. Sehingga pasca banjir yang tinggal hanya Nuh, istrinya dan tiga anaknya yakni Sam, Yafith dan Ham. Dari merekalah generasi manusia selanjutnya berkembang.

Patung-patung tadi tertanam hingga masa Ismail. Kata Ar-Raniri iblis mengeluarkan patung tadi kepada kaum Atman. Kaum itu kemudian membuat tiga ratus enam puluh patung. Mereka menjadi musyrik dengan tiga aliran. Aliran pertama menyatakan bahwa malaikat adalah anak perempuan Allah. Aliran kedua mengatakan patung-patung itu adalah sekutu dengan Allah. Aliran ketiga mengatakan patung-patung itu seperti Tuhan, patung-patung itu meminta syafaat kepada Allah bagi yang beriman kepadanya. Menurut mereka, keridhaan Allah terletak pada keridhaan patung itu (Ar-Raniri, 2011: 20),.

Selanjutnya Nuruddin Ar-Raniri membahas tentang perbedaan antara kafir dengan musyrik. Kafir adalah orang yang menutup kebenaran sebenarnya. Sementara musyrik adalah yang menyekutukan Allah. Nuruddin Ar-Raniri menilai Yahudi dan Nasrani adalah kafir.

Tab'iyyun dan Taba'iyyah menolak menyembah patung patung yang terbuat dari logam-logam. Menurut mereka segala jenis logam bukanlah entitas murni. Bagi mereka, entitas esensial adalah panas, dingin, kering dan basah. Karena dari empat entitas dasar itulah segalanya terwujud. Dua golongan tersebut di atas, menurut Nuruddin Ar-Raniri, terpecah kepada empat golongan dengan menyembah masing-masing entitas itu.

Selanjutnya Munjim dan Falakiyyah menolak untuk menyembah empat entitas dasar tadi dengan alasan keempat entitas itu bersifat pasif. Mereka lebih memilih untuk menyembah bintang-bintang seperti Zuhal (Saturnus), Musytari (Jupiter), Murih (Mars), Syams (Matahari), Zuhrah (Venus), Atarid (Merkuri) dan Qamar (Bulan). Menurut mereka, objekobjek tersebut aktif, lebih berpengaruh dan menjadi penentu kehidupan di bumi.

Tsanawiyah adalah ajaran yang menyembah Nur (terang) dan Zulmah (gelap). Mereka menilai segala wujud berasal dari dua entitas tersebut. Adapun yang menyembah terang disebut Yazdan dan yang menyembah gelap disebut Ahriman.

Majusi terbagi menjadi tiga aliran yakni Zamzamiyah, Syansuniyyah dan Samaniyyah. Ajaran Zamzamaniyah kata Ar-Raniri 
adalah ajaran yang meyakini Ibrahim tidak terbakar api karena beliau menyembah api (Ar-Raniri, 2011: 26). Dikatakan pula bagi siapa yang menyembah api tidak akan dibakar di neraka kelak. Sebagian golongan ini meyakini Iblis adalah sekutu Tuhan karena dia dijadikan dari cahaya Tuhan. Sementara aliran Syams menyembah api dan matahari karena meyakini kedua objek itu adalah Nur Allah. Aliran Samaniyyah dikatakan Ar-Raniri menyembah segala jenis cahaya, baik itu matahari, bulan, api dan sebagainya (Ar-Raniri, 2011: 28). Mereka meyakini segala cahaya itu adalah dari Nur Allah. Namun menjadi beragam karena Allah menjadikan keburukan.

Ar-Raniri mengidentikkan ajaran di atas dengan ajaran Hamzah Fansuri yang diuraikan dalam Asrar'Arifin: "Bahwa cahaya yang pertamatama cerai daripada Zat Allah itu Nur Muhammad" (Al-Attas: 170: 242). Ajaran Hamzah Fansuri ini juga diidentikkan dengan ajaran reinkarnasi milik Tanasukhiyyah, Jawhar Basith dalam filsafat, Wathaniyah, Barahimah dan Hululiyyah (Ar-Raniri, 2011: 30).

Menurut Ar-Raniri, sebagian ahli mengatakan Majusi termasuk ahli kitab. Sementara sebagiannya lagi mengatakan bukan. Di antara yang meyakini Majusi adalah bagian ahli kitab adalah Sayyidina Ali ra. Dikisahkan, awalnya mereka memiliki kitab suci. Namun ketika mereka melakukan suatu pelanggaran yakni menikahi saudara kandung, maka kitab tersebut diangkat dari mereka.

Majusi juga dinamai sebagai Sahibul Kitab Ar-Raniri karena seorang bernama Zardasyiyyah (Zarathustra, Zoroaster) yang mengaku dirinya nabi dan mengarang kitab bernama Zendufarand (Zend Avest). Kitab tersebut berisi berbagai aturan. Para pengikutnya terbagi menjadi tiga aliran yakni Zardasyiyyah, Mazdakiyyah dan Nusyirwaniyyah. Ajaranajaran tersebut menyatakan segala kehidupan berasal dari api, sehingga apilah yang harus disembah.

Dahriyyah atau Ateisme, tidak menyembah apapun. Menurut mereka ibadah itu tidak berguna. Segala entitas alam hanya mengikut hukumnya masing-masing. Tidak ada yang dapat dianggap superior di alam dan tidak berpengaruh bagi manusia kalau tidak ada dari entitas alam yang disembah. Manusia juga mengikuti hukum alamnya sendiri, yaitudilahirkan dari rahim ibu dan mati kembali ke tanah. Alam semesta bagi Ateisme, kata Ar-Raniri, telah ada sejak semula, tanpa permulaan (ArRaniri, 2011: 34). Perubahan-perubahan alam bukan ditentukan oleh suatu apapun melainkan karena faktor-faktor intrinsik alam sendiri yakni cuaca. Ajaran tersebut meyakini orang yang gemar berbuat kebaikan nyawanya akan menjelma manusia selama tujuh kali. Lalu dibangkitkan sebagai cahaya. Sementara yang berbuat keburukan seperti membunuh manusia 
atau hewan bernyawa, akan menjelma sebagai hewan seperti ular, kalajengking, anjing atau babi sebanyak tujuh kali. Lalu menjelma manusia. Bila berbuat baik, maka nyawanya menjelma manusia hingga tujuh kali lalu menjelma cahaya (Ar-Raniri, 2011: 35-37). Kata Ar-Raniri, ajaran demikian terdapat di Gujarat. Ajaran itu disebut Seroka, dengan gurunya bernama Warithya.

\section{Hukama}

Selanjutnya Ar-Raniri membahas tentang pandangan para filosof (bukama falasifah). Katanya, filosof meyakini bahwa alam itu tiada memiliki permulaan. Ia telah eksis bersama Allah sejak azali. Katanya pula, filosof meyakini segala maujudat tidak dijadikan Allah dari ketiadaan. Katanya juga, filosof meyakini segala manjudat dijadikan Allah tiada dengan ikhtiar. Keberadaan manjudat bagi Tuhan dilihat filosof umpama keniscayaan cahaya matahari, di mana matahari sendiri tiada kuasa menghentikan cahayanya.

Filosof juga meyakini segala maujudat tidak dijadikan dari ketiadaan, tetapi hanya menjelmakan segala sesuatu dari entitas yang telah ada sedia bersama-Nya. Dalam pandangan bukama, kata Nuruddin ArRaniri, doa hanya dipanjatkan sebagai bukti kelemahan hamba di hadapan Tuhan. Namun sejatinya hamba selalu berada dalam limpahan karunia Tuhan (Ar-Raniri, 2011: 38).

Selanjutnya Ar-Raniri mengatakan, dalam pandangan bukama, maksud daripada ibadah adalah agar serupada dengan Allah dengan kadar manusia. Juga hukama meyakini, rahmat Tuhan bukan kepada hamba, tetapi kepada diriNya saja.

Ar-Raniri melanjutkan kritiknya pada hukama dengan mengatakan bahwa mereka meyakini Allah tidak mengetahui perkara-perkara partikular. Pula meyakini Allah tidak kuasa merubah alam. Nuruddin ArRaniri mengatakan pandangan demikian adalah munkar akan qudrat Allah. Hukama juga dikatakan tidak percaya akan kebangkitan jasad pada hari berbangkit.

Hukama dikatakan telah membuat kesalahan dengan menganalogikan Tuhan dan makhluk dengan matahari dan panasnya. Pernyataan hukama yang meyakini keazalian dan kekekalan Hayula, yakni materi primer, adalah paham yang bertentangan dengan semua aliran teologi dalam Islam.

Sementara, kata Ar-Raniri, segala aliran teologi dalam Islam meyakini bahwa Allah menghendaki segala perkara dengan ikhtiar-Nya. Dan Allahlah yang mengatur segala perkara teknis di alam. 


\section{Qitiyyah dan Sufistaiyyah}

Selanjutnya Ar-Raniri membahas tentang ajaran Qitiyyah dan Sufistaiyyah. Ajaran tersebut terbagi tiga paham. Pertama, meyakini segala maujudat tidak memiliki hakitat. Karena, misalnya, terkadang api tidak membakar dan air tidak membasahi. Kedua, meyakini hakikat segala sesuatu itu tidak dapat diketahui. Ketiga, meyakini segala sesuatu tunduk pada kehendak pengamatnya; dan menjadikan segala sesuatu itu tidak diketahui karena tidak terindrai. Ajaran yang dikemukakan Ar-Raniri ini mirip dengan skeptisme. Ajaran ini tidak ingin membahas tentang Allah karena mengaku tidak mengetahuinya. Sebagian kalangan ini menurut ArRaniri mengatakan Allah memiliki tempat atau tunduk pada hukum ruang sebagaimana materi-materi. Sebagian lain dari kalangan ini berpendapat tidak perlu meykini akan Allah. Sebagiannya lagi meyakini sifat-sifat Allah adalah makhluk. Allah diyakini hanya punya empat sifat yakni ilmu, kehendak, mencipta dan kuasa. Ar-Raniri menganggap ajaran demikian sebagai kekufuran.

Disebutkan Qitiyyah dan Sufistaiyyah meyakini Al-Qur'an adalah makhkuk sekaligus bukan makhuk. Mereka juga meyakini surga dan neraka akan binasa. Dan mukmin tidak akan masuk neraka. Ar-Raniri mengklaim mereka itu kufur. Meereka meyakini kolam, titi dan neraca di akhirat kelak hanya istilah perlambangan. Kolam dianggap analogi dari air, titi itu maksudnya adalah agama dan mizan itu maksudnya adil. 'Arasy itu maksudnya malaikat. Kursiy itu maksudnya ilmu. Ar-Raniri menuduh keyakinan demikian adalah kafir. Sebagian mereka dikatakan tidak mengakui adanya azab kubur. Sebagian lainnya dari mereka dikatakan ArRaniri tidak mempercayai kelak akan dapat melihat Allah. (Ar-Raniri, 2011: 45)

\section{Tanasukiyyah atau Brahman}

Selanjutnya dibahas tentang taifah Tanasukiyyah. Aliran itu terbagi menjadi empat cabang. Lalu berkembang cabang-cabang lainnya hingga mencapai delapan puluh cabang. Aliran pertama, dikatakan meyakini Allah adalah cahaya. Segala cahaya dianggap datang dariNya. Ruh, api dan sebagaiya juga dari cahaya-Nya. Mereka dikatakan menyembah segala cahaya. Ajaran ini dikatakan adalah agama Brahman sebagaimana berkembang di India.

Tanasukiyyah dikatakan meyakini segala arwah adalah bagian dari organ Allah. Karena ajaran ini meyakini segala sesuatu datang dari Allah dan kembali kepada-Nya, maka Ar-Raniri menyimpulkan ajaran ini meyakini segala makhluk adalah bagian dari organ Allah. Dan Nuruddin 
Ar-Raniri mengatakan ajaran demikian adalah sesat (dalalab). Dikatakan Ar-Raniri , Hamzah Fansuri dan Syamsuddin As-Sumatraniuddin Sumatra'i berpaham demikian. Dikatakan juga ajaran ini meyakini kejadian (takwin) dengan yang menjadikan (mukawwin), dan aktivitas (tafa'ul) pengaktif (mufa'al) adalah satu.

Munawwiyah, yang juga dikatakan adalah bagian dari Tanasukiyyah, meyakini Haqq Ta'ala hulul dengan zat-Nya pada segala sesuatu yang kelihatan. Sehingga, kata Ar-Raniri, mereka menyembah benda yang dianggap elok pada pandangan. Merekalah kaum Hululiyyah, Jalaliyyah, Ghalabiyah, dan Rafidi. Kata Ar-Raniri, mereka meyakini Ali sebagai Allah.

Selanjutnya Ar-Raniri membahas tentang Manawiyyah yang berada di Cina, Tibet dan Kazakhstan yang mengawini istri, anak dan budak orang lain. Mereka dikatakan sebagai kafir. Keyakinan demikian dianggap identik dengan Nasrani yang oleh Ar-Raniri dikatakan meyakini Allah menyetubuhi Siti Maryam dan memperoleh anak yakni Nabi Isa.

Dikatakan juga oleh Ar-Raniri Tanasukiyyah itu meyakini Allah mengambil suatu Nur dari Diri-Nya. Lalu dibagi tiga bagian. Pertama menjadi surga dengan nama Makan al-Amkin. Kedua dijadikan segala malaikat yang dinamai Nafs Al-Ruhani. Katiga dijadikan semua manusia, yang dinamakan Nafs al-Ruhani. Karena itu, kata Ar-Raniri, diyakini surga, malaikat dan arwah itu kekal (Ar-Raniri, 2011: 50).

Dikatakan juga alam dunia menurut Tanasukiyyah dijadikan dari arwah dan surga. Malaikat berkediaman di surga dan arwah berkediaman di dunia. Ruh para nabi dan ulama naik ke langit untuk belajar wahyu. ArRaniri mengatakan pandangan demikian adalah bentuk kemungkaran atas wahyu yang dibawa Jibril.

Dikatakan Tanasukiyyah meyakini orang yang di alam arwah saling berdekatan akan saling mengenal di alam materi. Sementara yang sebaliknya akan bermusuh-musuhan di alam dunia.

Dikatakan pula Tanasukiyyah meyakini akibat kemurkaan Allah pada arwah, maka dicampakkannya ke bumi sehingga bercampurlah ia dengan lumpur dan tanah. Lalu satu bagian arwah diambil segenggam dari tanah sehingga zahirlah arwah itu menjadi nabi dan segala tumbuhan. Sehingga tubuh merasai kesakitan dan kenikmatan karena arwah merasakannya. Selanjutnya dikatakan ruh dapat masuk ke lembaga lain seperti hewan. Ajaran yang dinamakan Tanasukiyyah ini dikataran (ArRaniri, 2011: 52-53) terdapat di Gunung Merak Jawa. Mereka diklam kufur dan sesat. 


\section{Yahudi}

Ar-Raniri selanjutnya menulis tentang agama Yahudi. Ada empat orang nabi Yahudi yang menguasai Taurat yakni Musa, Harun, Yusa' dan Uzayr. Ar-Raniri mengatakan terdapat dua golongan Yahudi yakni Uzayriyah dan Samiriyyah. Uzayriyah muncul dari keyakinan Bani Israil bahwa kemampuan Uzayr memahami Taurat sebagai tanpa proses pembacaan sebelumnya karena dia adalah anak Allah. Sementara Samiriyyah dikatakan menyembah lembu. Alasannya manusia itu najis, tidak layak menyembah Allah. Bahwa lembu itu suci. Maka mereka menyembahnya. Dikatakan juga manusia tidak dapat menyembah Allah. Kalau saja dapat, tidak perlu diutus Nabi Musa as. Dikatakan juga Nabi Muhammad hanya diutus untuk Arab dan ajam, bukan untuk Bani Israil, karena mereka sudah punya kitab dan Rasul. Mustahil kitab suci mereka dihapuskan. Dikatakan oleh Ar-Raniri, Yahudi adalah sejahat-jahat kaum.

\section{Nasrani}

Ar-Raniri menyatakan hanya dua agama ahlul kitab, yaitu Yahudi dan Nasrani. Setelah membahas tentang Yahudi, kemudian Nuruddin ArRaniri membahas tentang Nasrani (Ar-Raniri, 2011: 60). Agama ini terbagi tiga golongan, yakni Malkaniyyah, Nasturiyyah dan Maryaqubiyyah. Ketiga aliran itu diambil dari nama tiga orang Nasrani yang belajar pada Yahudi yang menipu dengan mengaku pindah ke agama Nasrani. Tiga orang itu adalah Malkan (Ibrahim Madkour), Nastur dan Maryakub. Guru palsu itu bertujuan memecah-belah Nasrani dengan memberikan pengajaran-pengajaran yang berbeda pada tiga orang murid itu. Semua murid diminta untuk merahasiakan ajaran masing-masing.

Kepada Malkan dikatakan bahwa Isa itu adalah Allah yang turun ke bumi. Buktinya dia mampu menghidupkan yang telah mati dan menjadikan unggas dari tanah. Sementara seorang rasul tidak akan mampu demikan.

Kepada Nastur diajarkan Isa bukanlah manusia biasa karena mampu menghidupkan yang mati.

Kepada Mar Yakub dikatakan Isa adalah Allah dan anak Allah. Tuhan turun dari zatNya kepada lokus-lokus lain, Dia adalah tiga sekaligus satu.

Setelah guru tadi meninggal, ketiga murud itu berkumpul dan terjadi perselisisan tentang teologi Nasrani antara mereka. Eksesnya adalah peperangan antar pengikut masing-masing yang menyebabkan tewasnya empat puluh ribu orang.

Ar-Raniri menyebukan, sebagian kalangan Ahlus-sunnah Waljama'ah meyakini perpecahan Nasrani terjadi karena ketika Isa 
dituntut Bani Israil untuk menyampaikan Taurat, maka dia mampu melakukannya dengan baik. Namun sebagian Bani Israil menganggap yang disampaikan Isa tidak sempurna. Lalu Allah menghidupkan Uzayr sang rasul yang menguasai Taurat. Dia menyampaikan Taurat sesuai dengan yang disebutkan Isa. Namun masyarakat malah menggap Uzayr adalah anak Tuhan, karena kalau dia manusia, mustahil bisa hidup kembali setelah meninggal. Sebagian lagi menganggap Isa anak Tuhan. Alasannya, dia menguasai Taurat tanpa mempelajarinya terlebih dahulu. Dan Ar-Raniri mengatakan Nasrani adalah seburuk-buruk kaum karena menganggap Allah adalah Isa anak Maryam.

Ar-Raniri menegaskan bahwasanya Islam, adalah agama penyerahan diri secara total dan tulus kepada Allah. Barang siapa yang berpaling dari agama Islam, maka dia sesat. "Yakni berpegang kamu pada tali Allah yaitu Qur'an dan janganlah kamu ceraikan akan agama kamu dari pada agama Allah yaitu mazhab Ahlussunnah wal-jama'ah."

\section{Ahlus-sunnah Waljama'ah}

Selanjutnya Ar-Raniri membahas tentang mazhab Waljama'ah. Katanya, siapa saja yang menyalahi daripada Ahlussunnah Waljama'ah, maka jadilah ia ahli bidah, yakni orang yang mengada-ada dalam agama Islam. Orang demikian dikatakan adalah penghuni neraka. Mereka dianggap orang yang berpecah-belah (QS. 3: 105). Orang demikian diberikan azab yang pedih (QS. 45: 9-10)

Ar-Raniri menyebutkan sebuah hadits bersumber dari Sunan Abu Dawud, bahwa Nabi Muhammad telah memperingatkan bahwa ummatnya akan terpecah menjadi tujuh puluh tiga golongan. Semua akan masuk neraka kecuali Ahlus-sunnah Waljama'ah. Juga disambung dengan hadits bersumber dari Sunan Turmudhi yang menyatakan bahwa yang tidak dihimpun pada golongan sesat adalah yang berhimpun dengan jamaah yang banyak. (QS. 71-72)

Ar-Raniri mengatakan hanya ada satu jalan yang benar yaitu Ahlus-sunnah Waljama'ah. Yang lainnya adalah jalan setan. Disebutkan jalan setan itu adalah Jabariah, yaitu pandangan manusia hidup dengan paksaan mutlak; Qadariyah, pandangan manusia bebas mutlak; Tasybih, yang menyerupakan Tuhan dengan makhluk; Ta'til, tidak mengakui Tuhan memiliki sifat; Khariji, yaitu golongan yang memisahkan diri dengan Ali, yang meyakini pelaku dosa besar menjadi kafir yang disebut dengan Khawarij, dan; Rafidi, yakni himpunan sekte-sekte terutama Syi'ah (bandingkan, Nasution, 2006), 
Kata Nuruddin Ar-Raniri, Imam Hanafi mengatakan Ahlussunnah Waljama'ah itu bukam Khawarij, bukan Rafidi, bukan Tasybih dan bukan Ta'til.

Tetapi narasi Ahlus-sunnah Waljama'ah tidak ada dalam ucapan Nabi Saw. Beliau hanya mengatakan 'jama'ah' dan orang orang yang bersama dirinya dan para sahabatnyalah yang selamat di antara berbagai aliran, bukan aliran yang disusun dan dikodifikasi oleh Abu Hasan AlAsy'ari dan dipopulerkan oleh imam Al-Ghazali (Nasution dan Miswari, 2017). Ar-Raniri menegaskan pendapat dari Ibn Abbas bahwa semua aliran kecuali Ahlus-sunnah Waljama'ah adalah penghuni neraka.

Selanjutnya Ar-Raniri menunjukkan aliran-aliran yang katanya disepakati seluruh ulama Ahlus-sunnah Waljama'ah sebagai ajaran bidah, yaitu Rafidiyyah, Kharijiyyah, Jabariah, Kadariah, Jahamiyyiah (pimpinan Jahm Ibn Safwan) dan Murjiyyah (Murji'ah ).

\section{Rafidi}

Ar-Raniri menguraikan dua belas kelompok Rafidi dan menambahkan Isma'iliyyah. Pertama adalah 'Ali Al-Huluhiyyah atau Sabaiyyah. Dikatakan golongan ini meyakini Sayyidina Ali itu turun dari langit, yang melepaskan diri dari rupa uluhiyah menjadi rupa manusia. Dia turun ke bumi untuk melakukan beberapa urusan dan kembali ke langit.

Kedua, Rafidi 'Alawaiyyah atau Ghurabiyyah, dikatakan meyakini Jibril keliru membawakan wahyu. Seharusnya wahyu diturunkan kepada 'Ali, bukan Muhammad. Keyakini ini menurut Ar-Raniri adalah kufur, karena mengingkari QS. 3: 144 yang menegaskan bahwa Muhammad adalah rasul Allah.

Ketiga, Rafidi Abadiyyah, dikatakan aliran ini meyakini 'Ali dan Muhammad sama-sama sebagai rasul. Keempat Rafidi Syi'iyyah atau Imamiyyah, yang dikatakan melaknat Abu Bakar, Umar, Usman dan para sahabat lainnya yang berbaiat kepada selain 'Ali sebagai khalifah. Aliran ini juga dikatakan melebihkan Ali atas sebagala sahabat lainnya. Juga dikatakan aliran ini tidak membenarkan khalifah selain dari Bani Hasyim. Aliran ini dikatakan shalat dengan mendekap tangan kiri di atas tangan kanan, serta tidak ruku'. Aliran ini dikatakan kafir berdasarkan QS. 48: 29, yang menegaskan bahwa yang membenci sahabat-sahabat Rasul adalah kafir.

Kelima adalah Rafidi Isma'iliyyah. Kata golongan ini, "Nubuwah itu tiada berkendak lagi tiada memberi faidah di bumi." Kata Ar-Raniri, itu pandangan kufur karena dalam QS. 21: 107, Allah telah menegaskan bahwa Muhammad diutus sebagai Rahmat bagi seluruh alam. 
Keenam adalah Rafidi Zaydiyyah, kata Nuruddin Ar-Raniri mereka tidak berkiblat kepada ulama dan fuqaha (Ar-Raniri, 2011: 81). Mereka hanya berrshalawat kepada Ali dan dan anak cucunya. Paham demikian menurut Ar-Raniri adalah bidah karena bertentangan dengan paham Ahlus-sunnah Waljama'ah .

Ketujuh adalah Rafidi Abbasiyah, yakni yang mengucap shalawat kepada 'Abbad Ibn Abdul Muttallib. Aliran ini juga dianggap bidah karena bertentangan denga paham Ahlus-sunnah Waljama'ah .

Kedelapan adalah Rafidi Nawusiyyah. Golongan ini dianggap kafir bedasarkan QS. 15: 56 karena dianggap berputus asa dari rahmat Allah. Dikatakan bahwa do'a dan sedekah itu tidak memberi manfaat di dunia. Mereka juga meyakini bila ada yang beranggapan doa seseorang lebih utama daripada doa yang lainnya, maka keyakinan demikian tergolong kafir.

Kesembilan adalah Rafidi Tanasukiyyah. Aliran ini meyakini bila ruh kelah keluar dari jasad, maka ia masuk kepada lembaga lain. Ar-Raniri mengatakan paham demikian adalah kufur.

Kesepuluh adalah Raifidi Laghiyah (Ar-Raniri, 2011: 83). Mereka dikatakan mengutuk Mu'awwiyah, Talhah dan Zubayr. Kata Ar-Raniri sikap demikian amat salah. karena menurutnya, berrdasarkan Shahih Bukhari, Nabi Muhammad mengatakan Allah melaknat orang yang menyumpahi sahabatnya.

Kesebelas adalah Rafidi Rajiyyah. Aliran ini dikatakan meyakini Sayyidina Ali pada hari kiamat akan akan menuntut balas pada para seterunya. Dan suara guruh dan kilat diyakini sebalai suara cemeti Ali. ArRaniri mengatakan paham demikian adalah kufurr karena berrtentangan dengan Alquran, Hadits dan keyakinan Ahlus-sunnah Waljama'ah (ArRaniri, 2011: 84).

Keduabelas adalah Rafidi Mutarabbisyah. Aliran ini dikatakan menganjurkan untuk memerangi raja-raja Islam. Pula dikatakan mereka menganjurkan tidak perlu menyapu muzza (sepatu khuf). Ar-Raniri mengatakan keyakinan tersebut adalah kufur karena mewajibkan yang haram.

Adapun Rafidi Isma'iliyyah dikatakan meyakini terkadang Haqq Ta'ala menyerupai insan berperan sebagai nabi, wali dan imam untuk menyeru sekalian manusia kepada Islam, bila tidak demikian, maka manusia akan sesat. Aliran ini dikatakan berrkeyakinan pada itihad dan hulul.

Ada juga Rafidi Ta'biriyah atau Ishaqiyyah dan Zayyidiyah.

Ar-Raniri mengatakan bahwa Rafidi dimunculkan oleh orang Yahudi yang mengaku Muslim. Setelah Abu Bakar dibai'at oleh para 
sahabat, Ali berniat membunuh Yahudi itu. Tetapi dia melarikan diri. Setelah Ali diangkat sebagai khalifah, Yahudi itu menyebarkan ajaran bahwa Ali adalah Allah.

Ar-Raniri mengatakan Rafidi adalah aliran yang paling jahat. Mengutip Musnad Ahmad, Ar-Raniri mengatakan bahwa Nabi Muhammad telah memperingatkan akan keberadaan Rafidi yang akan menjual agama. Dikatakan Nabi Muhammad memesankan agar penganut aliran tersebut untuk dibunuh (Ar-Raniri, 2011: 87)

\section{Khawarij}

Ar-Raniri mengatakan bahwa Khawarij terbagi menjadi dua belas kaum. Pertama adalah Khawarij Azraqiyah. Mereka dikatakan meyakini "... Mukmin dalam mimpinya tiada sekali-kali melihat kebajikan dari karena wahyu itu sudahlah putus." (Ar-Raniri, 2011: 88). Ar-Raniri menghukum golongan ini sebagai kaum kufir.

Kedua Khawarij Ibaghiyyah. Mereka dikatakan meyakini iman adalah ucapan, sementara amal dan niat hukumnya sunnah. Ar-Raniri mengatakan paham demikian adalah bidah dengan alasan tunggal yakni karena bertentangan dengan iktikad Ahlus-sunnah Waljama'ah yang meyakini bahwa iman itu diucapkan dengan lisan, dibenarkan dengan hati dan kesempurnaannya adalah amal.

Ketiga adalah Khawarij Tha'libiyyah. Mereka dikatakan meyakini kebaikan itu datang dari Allah dan keburukan datang dari hamba. Sementara itu mereka juga meyakini Muslim yang berbuat dosa adalah kufur. Ar-Raniri menentang ajaran ini dengan alasan sebagaimana dikutip dari QS. 37: 37, yang menyatakan bahwa diri dan perrbuatan manusia dijadikan oleh Allah.

Keempat adalah Khawarrrij Ghaliyyah. Mereka dikatakan meyakini shalat berrjama'ah bukan sunat hukumnya. Dikatakan paham demikian adalah fasiq dan bidah karena berrsalahan dengan iktikad Ahlus-sunnah Waljama'ah .

Kelima adalah Khawarrij Khalafiyyah. Mereka dikatakan tidak takut dengan kekafiran sehingga dianggap paham demikian adalah kekafiran. Paham ini juga dikatakan meyakini Ali tidak layak menjadi khalifah dan mereka tidak meyakini kekhalifahan. Paham demikian dikatakan kufur karena berrtentangan dengan paham Ahlus-sunnah Waljama'ah .

Keenam adalah Khawarrrij Kathriyyah. Mereka dikatakan meyakini bahwa membayar zakat tidak wajib. Alasan mereka karena kita tidak tahu status sebenarnya penerima zakat adalah mukmin atau kafir. 
Paham demikian dikatakan Ar-Raniri

(91) sebagai kufur karena bertentangan dengan QS. 2: 43, 83.

Ketujuh adalah Khawarrij Mu'tazilah. Yakni paham khawarij yang diadopsi Mu'tazilah. Mereka dikatakan meyakini bila orang mukmin melakukan dosa besar, maka terlepaslah imannya. Ar-Raniri mengatakan paham demikian adalah kufur. Alasannya, dengan mengutip QS. 4: 48 dan 116, bahwa Allah dapat mengampuni segala dosa kecuali menyekutukanNya. Pula ajaran ini dikatakan meyakini manusia tidak akan dapat melihat Allah di akhirat kelak. Dan Raniri juga mengatakan paham demikian adalah kufur. Karena, dengan mengutip QS. 75: 22-23, dia mengatakan Allah dapat dilihat di surga dengan cara hulul. "Kami lihat akan Haqq Ta'ala dalam syurga dengan hulul dan tiada berhingga dan tiada dengan kebetapaan seperti Haqq Ta'ala melihat kami dan ada Ia tiada berhingga dan tiada kebetapaan. Demikian lagi kami lihat akan Dia tiada berhingga dan tiada kebetapaan seperti kami lihat akan segala suatu yang kelihatan" (Ar-Raniri, 2011: 92-93).

Kedelapalan adalah Khawarij Maymuniyyah. Mereka dikatakan meyakini bahwa mempercayai yang gaib adalah kebatilan. Dikatakan juga aliran ini meyakini pikiran mukmin dan kafir adalah sama. Ar-Raniri mengatakan paham demikian adalah kufur karena QS. 2: 2-3 telah menegaskan bahwa Alquran ditujukan sebagai petunjuk kepada yang mempercayai eksistensi yang gaib.

Kesembilan adalah Khawarij Muhakkamiyah. Mereka dikatakan meyakini Allah tidak menghukumi atas segala makhluk-Nya dengan suatu hukum. Ar-Raniri (Ar-Raniri, 2011: 94) mengatakan paham demikian adalah kufur. Alasannya, Allah telah menegaskan dalam QS. 5: 1, 3: 40 dan 22: 18 bahwa Dia melakukan apa yang Dia kehendaki dan memberlakukan hukum.

Kesepuluh adalah Khawarij Akhnasiyyah. Mereka dikatakan meyakini matahari, bulan dan bintang bukan makhluk Allah. Ar-Raniri mengatakan paham demikian adalah kufur. Alasannya, QS. 16: 12 dan 7: 54 telah menegaskan bahwa matahari, bulan dan bintang adalah bagian dari titah Allah(Ar-Raniri, 2011: 94).

Kesebelas adalah Khawariji Ajiyyah atau Majhuliyyah. Mereka dikatakan meyakini iman seseorang tiada dapat diketahui manusia sehingga tidak dapat dikatakan seseorang itu adalah mukmin. Juga paham ini dikatakan meyakini seorang yang berniat berbuat dosa, ia sudah termasuk kafir. Ar-Raniri mengatakan paham demikian adalah kufur karena bertentangan dengan paham Ahlus-sunnah Waljama'ah.

Keduabelas adalah Khawarij Sumrakhiyyah. Mereka dikatakan meyakini bahwa perempuan itu seperti hamba atau mainan (bunga- 
bungaan), sehingga harus disetubuhi terlebih dahulu tanpa menikahinya. Ar-Raniri mengatakan paham demikian adalah kufur. Alasannya, Allah telah menegaskan dalam QS. 17: 32 bahwa zina itu tidak boleh didekati.

Ar-Raniri juga mengatakan bahwa sebagian golongan Khawarij meyakini bahwa Ali adalah kafir. Dan meyakini tidak ada ummat Muhammad yang dapat dipastikan sebagai mukmin kecuali Abu Bakar dan Umar. Paham demikian menurut Ar-Raniri adalah kekufuran (Ar-Raniri, 2011: 96).

Ar-Raniri mengisahkan bahwa Nabi Mumammad pernah menegaskan bahwa siapa yang mengasihi Usman dan Ali adalah mukmin dan siapa yang membenci mereka berdua adalah orang munafik.

Dikatakan Ar-Raniri bahwa Ali pernah mengatakan bahwa orang yang mengasihi dirinya secara berlebihan dan membencinya secara berlebihan akan menuai kebinasaan (97). Dikatakan juga bahwa Nabi Muhammad pernah mengatakan bahwa Khawajij adalah anjing neraka.

\section{Jabariah}

Ar-Raniri mengatakan Jabariah (Jabarriyah) terdiri dari dua belas golongan. Pertama adalah Jabariah Mudratiyyah. Ar-Raniri mengatakan golongan ini meyakini kebaikan dan kejahatan hanya dari Allah, bukan dari hamba. Paham demikian dikatakan kufur. Alasannya QS. 32: 17 telah menegaskan bahwa Allah membalas segala perbuatan hamba (Ar-Raniri, 2011: 99).

Kedua adalah Jabariah Fa'iliyyah. Ar-Raniri mengatakan golongan ini meyakini perbuatan adalah dari hamba, tetapi tidak memiliki kuasa. Paham demikian dikatakan bidah. Alasannya, QS. 16: 98 telah menyatakan bahwa Allah telah memberikan manusia penglihatan, pendengaran dan hati.

Ketiga adalah Jabarirah Ma'iliyyah. Ar-Raniri mengatakan golongan ini meyakini doa dan sedekah tidak memiliki manfaat. Paham demikian dikatakan bidah. Alasannya doa dan sedekah memadamkan murka Allah (Ar-Raniri, 2011: 100).

Keempat adalah Jabarirah Maqru'iyyah. Ar-Raniri mengatakan golongan ini meyakini ketaatan tidak menghasilkan kebaikan dan kemaksiatan tidak menghasilkan keburukan. Karena kebaikan dan keburukan hanya dari Allah, bukan dari perbuatan hamba. Paham demikian dikatakan kufur. Alasannya paham demikian adalah bentuk keputusasaan. Padahal QS. 39: 53 telah menyatakan bahwa manusia dilarang berputus asa dari rahmat Allah.

Kelima adalah Jabarirah Najjariyyah. Ar-Raniri mengatakan golongan ini meyakini kemaksiatan, keburukan, kekefuran dan kekafiran 
itu bukan datang dari Allah, karena bila demikian berarti Allah zalim. Mereka meyakini Allah tidak mengurus semua perkara. Paham demikian dikatakan kufur. Alasannya QS. 76: 30 telah menyatakan bahwa makhluk tiada berkehendak, melainkan Allah yang menghendaki. Mereka juga dikatakan meyakini Allah tidak dilihat di akhirat (Ar-Raniri, 2011: 101).

Keenam adalah Jabarirah Darariyyah. Ar-Raniri (Ar-Raniri, 2011: 102) mengatakan golongan ini meyakini kemaksiatan tidak mempengaruhi iman dan kekufuran tidak mempengaruhi ketaatan. Aliran ini dikatakan juga meyakini usaha bukan dari hamba tetapi perbuatan hamba itu dijadikan oleh Allah. paham demikian dianggap bi'ah karena bertentangan dengan paham Ahlus-sunnah Waljama’ah.

Ketujuh adalah Jabarirah Kasadiyyah. Ar-Raniri mengatakan golongan ini meyakini pahala dan siksa tidak bertambah dengan kebaikan dan kejahatan. Paham demikian dikatakan Kufur. Alasannya QS. 99: 7-8 telah menyatakan bahwa siapa saja yang berbuat kebaikan dan keburukan sekecil apapun dihihat Allah (Ar-Raniri, 2011:103).

Kedelapan adalah Jabariah Sabiqiyyah. Ar-Raniri mengatakan golongan ini meyakini bahagia dan celaka telah ditetapkan sejak azal di Lawh Mahfudz. Karena itu ketaatan tidak bermanfaat dan kemaksiatan tidak dimurkai. Paham demikian dikatakan kufur. Alasannya QS. 32: 17 telah menyatakan bahwa Allah membalas apa saja yang diperbuat hamba (Ar-Raniri, 2011: 103).

Kesembilan adalah Jabarirah Hubbiyyah. Ar-Raniri mengatakan golongan ini meyakini Maha Pengasih tidak menyiksa kekasih-Nya. Paham demikian dikatakan kufur. Alasannya QS. 5: 18 telah menyatakan bahwa Allah mengampuni siapa saja yang Dia kehendaki dan mengazab siapa saja yang Dia kehendaki (Ar-Raniri, 2011:104).

Kesepuluh adalah Jabarirah Fawqiyyah. Ar-Raniri mengatakan golongan ini meyakini Allah itu dua, satu di darat dan satu di laut. Mereka juga dikatakan meyakini yang nyata hanya surga, sementara neraka tidak nyata. Mereka tidak takut siksa. Paham demikian dikatakan kufur. Alasannya QS. 18: 11 telah menyatakan bahwa bahwa Allah itu satu (ArRaniri, 2011:105).

Kesebelas adalah Jabarirah Fikriyyah. Ar-Raniri mengatakan golongan ini meyakini berpikir lebih utama daripada ibadah. Paham demikian dikatakan kufur. Alasan Ar-Raniri, maksud ibadah sesaat lebih baik daripada ibadah tujuh puluh tahun maksudnya adalah ibadah sunnat, bukan ibadah fardu. Karena menurut Ar-Raniri banyak hadits yang menyatakan sujud, shalat, meninggal dengan membawa iman dan haji mabrur adalah perbuatan-perbuatan yang utama (Ar-Raniri, 2011:106107). 
Keduabelas adalah Jabarirah Jaysyiyyah. Ar-Raniri mengatakan golongan ini meyakini orang beriman yang mensucikan diri tidak perlu beramal. Paham demikian dikatakan kufur. Alasannya QS. 15: 99 telah menegaskan Allah memerintahkan untuk menyembah Allah hingga mati.

Di samping itu, Ar-Raniri menerangkan kepercayaan-kepercayaan lainnya dari Jabariah: Dikatakan mereka meyakini Allah memberi pahala atas kebaikan dan tidak mendera karena berbuat buruk. Juga dikatakan mereka meyakini segala perbuatan buruk tidak akan ditanyai karena perbuatan-perbuatan itu dari Allah.

Dikatakan ada juga Jabariah yang meyakini perbuatan baik dan perbuatan buruk datang dari Allah. Ar-Raniri menegaskan paham demikian adalah kufur. Alasannya, paham demikian dianggap sama dengan mensifatkan Allah dengan sifat-sifat yang buruk sehingga Allah adalah zalim (Ar-Raniri, 2011:108).

Dikatakan ada juga keyakinan Jabariah yang meyakini perbuatan hanya tampilan semu semata. Hamba hanya seperti daun gugur yang tidak punya kuasa atas angin. Ar-Raniri menyatakan paham demikian adalah kufur (Ar-Raniri, 2011:109).

Dikatakan ada juga keyakinan Jabariah yang meyakini Allah telah menjadikan segala sesuatu. Maka segala yang muncul tidak ada sangkutpautnya lagi dengan Allah. Ar-Raniri menyatakan paham demikian adalah kufur.

Dikatakan ada juga keyakinan Jabariah yang meyakini Allah menghidupkan orang kafir di neraka, lalu dimatikan dan tidak dihidupkan lagi. Ar-Raniri menyatakan paham demikian adalah kufur (Ar-Raniri, 2011:109-110).

Dikatakan ada juga keyakinan Jabariah yang meyakini Allah menyiksa hamba-Nya karena perbuatan-Nya dengan mencari-cari alasan dari perbuatan hamba-Nya. Ar-Raniri menyatakan paham demikian adalah kufur.

Dikatakan lagi ada juga keyakinan Jabariah yang meyakini setiap gerakan yang terbesit di dalam hati, baik kebaikan maupun keburukan, harus dilaksanakan. Ar-Raniri menyatakan paham demikian adalah kufur (Ar-Raniri, 2011:110).

Dikatakan ada juga keyakinan Jabariah yang meyakini bila seseorrang telah mencapai derajat menjadi kekasih Allah, maka dia tidak memiliki kesalahan apapun, tidak perlu baginya beribadat lagi karena bertafakkur adalah ibadat baginya. Ar-Raniri menyatakan paham demikian adalah kufur (Ar-Raniri, 2011:111).

Dikatakan ada juga keyakinan Jabariah yang meyakini segala perbuatan manusia adalah satu pekerjaan yang sama dari Adam dan Hawa. 
Maka apapun yang dilakukan seseorang tidak boleh diperkarakan. ArRaniri) menyatakan paham demikian adalah kufur (Ar-Raniri, 2011:111.

Dikatakan ada juga keyakinan Jabariah yang meyakini barang siapa yang belajar ilmu, maka jadilah ia syarikat pada arta segala manusia. Dan siapa saja yang menegahkan (melarang) dia jadilah kafir. Ar-Raniri menyatakan paham demikian adalah kufur.

Dikatakan pula ada juga keyakinan Jabariah yang meyakini tidak ada apapun yang difardukan Allah kepada manusia. Kalau seseorang ingin melakukan atau meninggalkan suatu maka itu terserah dia. Ar-Raniri menyatakan paham demikian adalah kufur (Ar-Raniri, 2011:112).

Dikatakan ada juga keyakinan Jabariah yang meyakini setiap orang telah dipastikan ia beriman atau kufur. Ar-Raniri menyatakan paham demikian adalah kufur.

Lalu dikatakan ada juga keyakinan Jabariah yang meyakini, "bahwa boleh berbuat segala ibadat itu, tiada wajib mengulang-ulang dia", ArRaniri menyatakan paham demikian adalah kufur (Ar-Raniri, 2011: 112).

Dikatakan ada juga keyakinan Jabariah yang meyakini mukmin bukan hakikatnya mukmin dan kafir bukan hakikatnya kafir, karena semua predikat itu berubah dalam akibat. Ar-Raniri menyatakan paham demikian adalah kufur.

Selanjutnya dikatakan ada juga keyakinan Jabariah yang meyakini mengucap syahadat tidak serta-merta membuat seseorang menjadi mukmin. Ar-Raniri menyatakan paham demikian adalah kufur (Ar-Raniri, 2011:113).

Dikatakan ada juga keyakinan Jabariah yang tidak mempercayai hari kiamat. Ar-Raniri menyatakan paham demikian adalah bidah (ArRaniri, 2011:113).

\section{Kadariah}

Ar-Raniri mengatakan Kadariah (Qadariyyah) terbagi menjadi dua belas golongan.

Golongan pertama meyakini boleh mengerjakan yang fardu, tetapi mereka mengatakan tidak boleh melakukan yang sunat. Ar-Raniri mengatakan keyakinan demikian adalah kufur. Alasannya, Karena mereka melarang melakukan ibadah sunat. Padahal Sahih Bukhari telah menegaskan bahwa yang membenci sunat Nabi Muhammad bukan termasuk ummatnya (Ar-Raniri, 2011: 114).

Kedua adalah Kadariah Thanawiyyah. Dikatakan golongan ini meyakini boleh mengerjakan sunat, tetapi melarang melakukan fardu. Dikatakan juga mereka melakukan shalat Zuhur, Ashar dan lainnya masing-masing dua rakaat. Ar-Raniri mengatakan keyakinan demikian 
adalah kufur. Alasannya, mereka menolak melaksanakan fardu (Ar-Raniri, 2011: 113).

Ketiga adalah Kadariah Kaykaniyyah. Dikatakan golongan ini meyakini manusia tidak dapat mengetahui apakah perbutan adalah makhluk atau bukan. Ar-Raniri mengatakan keyakinan demikian adalah kufur. Alasannya, QS. 37: 96 telah menegaskan bahwa manusia dan perbutannya adalah ciptaan Allah (Ar-Raniri, 2011:115).

Keempat adalah adalah Kadariah Syaytaniyyah. Dikatakan golongan ini meyakini setan adalah manifestasi Tuhan karena tidak memiliki wujud yang nyata. Ar-Raniri mengatakan keyakinan demikian adalah kufur. Alasannya, karena mereka menyekutukan Allah (Ar-Raniri, 2011: 116).

Kelima adalah Kadariah Syarikiyyah. Dikatakan golongan ini meyakini manusia dan setan yang menjadikan kejahatan dan Allah yang menjadikan kebaikan. Ar-Raniri mengatakan keyakinan demikian adalah kufur. Alasannya, paham demikian meyakini ada dua yang menjadikan.

Keenam adalah Kadariah Wahmiyyah. Dikatakan golongan ini meyakini niat lebih mulia daripada perbuatan. Aliran ini dikatakan mengatasnamakan Hadits berbunyi "niyyat Al-mu'min khayr min al-'amal". Ar-Raniri mengatakan keyakinan demikian adalah kufur. Alasannya karena mereka menafikan amal dan hanya mengandalkan niat saja (ArRaniri, 2011:116).

Ketujuh adalah Kadariah Ruwaydiyyah. Dikatakan golongan ini meyakini siapa yang kufur pada Allah harus beriman pada semua makhluk. Ar-Raniri mengatakan keyakinan demikian adalah kufur. Alasannya, aliran ini menafikan ilmu Allah dan menyabitkan ilmu pada makhluk (Ar-Raniri, 2011:117).

Kedelapan adalah Kadariah Nakisiyyah. Dikatakan golongan ini meyakini untung baik dan untung jahat bukan dari Allah. Ar-Raniri mengatakan keyakinan demikian adalah kufur. Alasannya karena aliran ini meyakini ada pencipta lain selain Allah (Ar-Raniri, 2011:117).

Kesembilan adalah Kadariah Mutabarriyyah. Dikatakan golongan ini meyakini pelaku dosa besar tidak diterima taubatnya. Ar-Raniri (118) mengatakan keyakinan demikian adalah kufur. Alasannya, QS. 4: 16 telah menegaskan Allah menerima taubat hamba-Nya dan Dia amat pengasih.

Kesepuluh adalah Kadariah Qistiyyah. Dikatakan golongan ini meyakini alam dunia dan alam akhirat itu tersembunyi. Eksistensinya seperti mimpi. Ar-Raniri menegaskan paham demikian adalah kufur. Alasannya, QS. 72: 15 telah menegaskah bahwa kaum Qistiyyah adalah bahan bakar neraka (Ar-Raniri, 2011:118). 
Kesebelas adalah Kadariah Nazzamiyyah. Dikatakan golongan ini meyakini Allah tidak boleh dinamai dengan sesuatu karena setiap kesesuatuan adalah makhluk. Ar-Raniri mengatakan keyakinan demikian adalah kufur. Alasannya, QS. 6: 19 telah menegaskan bahwa syahat terbesar adalah mengatakan 'Allah' (Ar-Raniri, 2011:119).

Kedua belas adalah Kadariah Mu'tazilah. Dikatakan golongan ini meyakini ibadah itu tidak berguna. Karena kebahagiaan maupun kesengsaraan bagi setiap orang telah ditetapkan sejak rahim. Ar-Raniri mengatakan keyakinan demikian adalah kufur (Ar-Raniri, 2011: 120).

Ar-Raniri mengatakan ada pula kalangan Kadariah meyakini Allah menyuruh dan memilikkan segala pekerjaan hamba kepada hamba sehingga hambalah yang menghendaki pekerjaan itu, bukan dengan kehendak, izin dan ketetapan Allah. Maka keyakinan demikian dikatakan Ar-Raniri adalah kekufuran. Karena menyatakan ada yang menjadikan selain Allah.

Ar-Raniri juga mengatakan sebagian dari Kadariah ingkar pada sifat Allah. Paham demikian dikatakan kufur.

Ar-Raniri juga mengatakan sebagian dari Kadariah meyakini AlQur'an adalah makhluk. Paham demikian dikatakan kafir. Alasannya, ada Hadits yang mengatakan siapa yang mengatakan Al-Qur'an adalah makhluk maka ia kafir. Ia juga mengatakan Hamzah Fansuri dalam Asrar Al-Arifin menulis, Al-Qur'an yang dibawa Jibril adalah makhluk (ArRaniri, 2011:121).

Ar-Raniri juga mengatakan sebagian Qadariyah menyakini surga dan neraka bukan makhluk dan tidak kekal. Ia mengatakan paham demikian adalah kufur.

Ar-Raniri juga mengatakan, sebagian dari Jabariah meyakini amal itu tidak dibalas, ia dari hamba juga. Dan tidak dapat diketahui apakah seseorang diberi pahala atau siksa. Dia mengatakan paham demikian adalah kufur (Ar-Raniri, 2011:121-122).

Ar-Raniri juga mengatakan, sebagian dari Kadariah meyakini Allah tidak menciptakan setan. Dan yang meyakini setan adalah ciptaan Allah berarti kufur. Dia mengatakan paham demikian adalah kufur (ArRaniri, 2011:122).

Ar-Raniri juga mengatakan, sebagian dari Kadariah meyakini segala amal adalah makhluk Allah melainkan iman dan kufur.

Ar-Raniri juga mengatakan, sebagian dari Kadariah meyakini kitab Allah yang diturunkan dari langit tidak mansukh (dihapus) sehingga wajib Berbuat amal akan dia. Dia mengatakan paham demikian adalah kufur (Ar-Raniri, 2011:122). 
Dengan demikian, Ar-Raniri mengatakan semua keyakinan Kadariah seperti Majusi. Alasannya, ada Hadits yang menyatakan bahwa Kadariah adalah ummat Nabi Muhammad yang majusi dan Nabi Muhammad memerintahkan untuk membunuh mereka. Bila mereka sakit, tidak boleh dijenguk, kalau mati, tidak boleh dishalatkan sebagaimana tertera dalam Sunan Abu Dawud, Nabi Muhammad melarang duduk dan jangan berdebat dengan orang-orang dari golongan Kadariah.

Jahamiyyah

Ar-Raniri mengatakan Aliran Jahamiyyah terdiri dari dua belas golongan. Pertama adalah Jahamiyyah Mu'attaliyyah. Ar-Raniri mengatakan aliran ini meyakini Nama dan Sifat Allah adalah makhluk. Disebutkan paham demikian adalah kufur. Alasannya, keyakinan demikian menafikan keberadaan Sifat sejak azal. Padahal QS. 7: 180 telah menyatakan untuk meninggalkan orang yang ingkar atas nama dan sifat Allah (Ar-Raniri, 2011: 125).

Kedua adalah Jahamiyyah Marabitiyyah. Ar-Raniri mengatakan aliran ini meyakini Sifat Allah yakni ilmu, kehendak dan lainnya adalah makhluk dan hamba bukan makhluk. Disebutkan paham demikian adalah kufur. Alasannya, keyakinan seperti itu menganggap Allah baharu dan makhluk itu kekal. padahal QS. 52: 35 telah menyatakan bahwa Allah menjadikan makhluk dari tiada menjadi ada (Ar-Raniri, 2011:125-126).

Ketiga adalah Jahamiyyah Mutaraqiyyah. Ar-Raniri mengatakan aliran ini meyakini Allah maujud di setiap tempat. Mereka melandaskan keyakinan pada QS. 20: 7 yang menyatakan Allah bertempat di 'Arasy. Juga sebuah Hadits Qudsi menyatakan Allah berada di setiap tempat. Disebutkan paham demikian adalah kufur. Alasannya, tempat dan yang menempati adalah baharu. Sehingga menyatakan Allah baharu adalah kekafiran (Ar-Raniri, 2011:126-127).

Keempat adalah Jahamiyyah Iradiyyah. Ar-Raniri mengatakan aliran ini meyakini mukmin yang masuk neraka tidak akan keluar. Disebutkan paham demikian adalah kufur. Alasannya, QS. 19: 72 telah menyatakan bahwa yang takut pada Allah akan keluar dari neraka, sementara yang kafir tidak. Pula diyakini Ar-Raniri bahwa QS. 48: 116 telah menyaakan bahwa Allah dapat mengampuni semua dosa kecuali syirik (Ar-Raniri, 2011:128).

Kelima adalah Jahamiyyah Haraqiyyah. Ar-Raniri mengatakan aliran ini meyakini bila telah hangus terbakar neraka, tidak akan hidup lagi. Disebutkan paham demikian adalah kufur. Alasannya, QS. 33: 65 telah mengatakan isi neraka kekal di dalamnya. juga QS. 173 telah menyatakan, ketika kulit isi neraka terbakar, maka diganti kulit yang lain supaya mereka merasakan azab (Ar-Raniri, 2011: 129). 
Keenam adalah Jahamiyyah Makhluqiyyah. Ar-Raniri mengatakan aliran ini meyakini Alquran adalah makhluk. Disebutkan paham demikian adalah kufur. Alasannya, QS. 39: 28 telah menyatakan Aquran yang turun dengan bahasa Arab itu bukan makhluk (Ar-Raniri, 2011: 129-130).

Ketujuh adalah Jahamiyyah Ghayriyyah. Ar-Raniri mengatakan aliran ini meyakini hisab dan Mungkar-Nangkir tidak nyata. Disebutkan paham demikian adalah kufur. Alasannya, QS. 14: 27 yang menyatakan tentang ketetapan Allah, dikatakan membahas konteks ketetapan adanya siksa kubur (Ar-Raniri, 2011: 128).

Kedelapan adalah Jahamiyyah Faniyyah. Ar-Raniri mengatakan aliran ini meyakini surga dan neraka akan binasa. Paham demikian dikatakan kufur. Alasannya, QS. 5: 119 telah menyatakan bahwa mukmin akan ditempatkan di surga dan mereka kekal di dalamnya. Tetapi Ar-Raniri mengatakan, kekekalan surga dan neraka tidak sekekal wajah Allah sebagaimana disebutkan dalam QS. 28: 88 (Ar-Raniri, 2011: 131).

Kesembilan adalah Jahamiyyah Zanadiqiyyah. Ar-Raniri mengatakan aliran ini meyakini alam itu kekal, dan hal yang diketahui itu ada sesuatu. Paham demikian dikatakan adalah iktikad Hamzah Fansuri dan Syamsuddin As-Sumatrani (bandingkan, Azra, 2002: 118). Ar-Raniri menyatakan paham demikian adalah kufur. Alasannya, QS. 13: 16 telah menyatakan bahwa Allah yang menjadikan segala sesuatu. Ar-Raniri menambahkan, Ahlus-sunnah Waljama'ah sepakat siapa yang meyakini ma'lum, maksudnya, objek pengetahuan Tuhan itu ada sesuatu, maka dia itu kafir. Dikatakan mereka adalah yang meyakini eksistensi materi primer dan a'yan tsabitah (lihat, Miswari, 2016: 113).

Kesepuluh adalah Jahamiyyah Lafziyyah. Ar-Raniri mengatakan aliran ini meyakini yang melafazkan dan yang dilafazkan adalah sama, Alquran itu kalam yang dilafazkan. Paham demikian dikatakan kufur. Dengan demikian disimpulkan mereka meyakini kalam yang dibaca itu bukan firman Allah. Paham demikian dikatakan seperti paham Wahdatul Wujud sebagaimana diyakini Hamzah Fansuri. Karena dalam Asrar Al'Arifin telah disebutkan bahwa Alquran yag dibawa Jibril dapat disebut makhluk karena telah terpisah dengan Zat (Miswari, 2014: 50). Paham demikiian disebut kufur. karena QS. 39: 28 dan 12: 2 tela menyatakan Alquran yang dibawa Jibril dengan bahasa Arab bukan makhkuk (ArRaniri, 2011:133).

Kesebelas adalah Jahamiyyah Qabriyyah. Ar-Raniri mengatakan aliran ini meyakini mayat tidak merasai azab, kesakitan hanya dirasai pada sakaratul maut. Paham demikian dikatakan kufur. Alasannya, QS. 52: 47 dan 40: 46 telah menyatakan orang kafir akan merasai azab neraka. Serta 
banyak hadits yang menyatakan keberadaan siksa kubur (Ar-Raniri, 2011:134).

Keduabelas adalah Jahamiyyah Waqifiyyah. Ar-Raniri mengatakan aliran ini meyakini Nabi Muhammad dan hamba melihat Allah di alam dunia. Paham demikian dikatakan kufur. Dikatakan juga aliran ini meyakini Alquran adalah kalam yang menilik (melihat dengan mata batin) dan yang membaca adalah makhluk. Paham demikian juga disebut kufur (Ar-Raniri, 2011:135-136).

Mereka juga dikatakan meyakini Allah berdiri di antara langit dan bumi. Paham demikian dianggap kufur. Alasannya, QS. 7: 143 telah menyatakan kita tidak akan dapat melihat Allah di dunia.

\section{Murji'ah}

Ar-Raniri mengatakan aliran Murji'ah terdiri dari dua belas golongan. Pertama adalah Murji'ah Tarikiyyah. Ar-Raniri mengatakan aliran ini meyakini setelah beriman, tidak wajib melakukan fardu lainnya. Dikatakan golongan ini juga meyakini Allah hanya menciptakan makhluk, tidak melarang mereka melakukan keburukan dan tidak memerintahkan melakukan kebaikan (Ar-Raniri, 2011:137). Dikatakan paham demikian adalah kufur. Alasannya, QS. 16: 90 dan 7: 28 telah menegaskan bahwa Allah telah menyuruh berbuat kebaikan dan melarang berbuat keburukan.

Kedua adalah Murji'ah Sabi'iyyah. Ar-Raniri mengatakan aliran ini meyakini siapa saja yang beriman dan bersyahadat, sama baginya berbuat taat atau tidak dan tidak akan dia menjadi murtad dan tidak akan dia (dianggap) berbuat dosa besar. Dikatakan paham demikian adalah kufur. Alasannya, QS. 5: 100 telah menegaskan bahwa kejahatan dan kebajikan itu tidak sama (Ar-Raniri 138).

Ketiga adalah Murji'ah Rajaiyyah. Ar-Raniri mengatakan aliran ini menyembah matahari, bulan dan bintang. Dikatakan perbuatan demikian adalah kufur. Alasannya, QS. 41: 37 telah menegaskan untuk tidak sujud pada matahari, bulan dan bintang (Ar-Raniri , 138-139).

Keempat adalah Murji'ah Syakiyyah. Ar-Raniri mengatakan aliran ini meyakini Allah adalah substansi dan aksiden. Dikatakan paham demikian adalah kufur. Alasannya, QS. 42: 11 telah menegaskan bahwa Allah tidak menyerupai apapun.

Kelima adalah Murji'ah Bahsyamiyyah. Ar-Raniri mengatakan aliran ini meyakini iman itu ilmu. Maka yang tidak berilmu adalah kafir. Ar-Raniri tidak memberikan keterangan tambahan tentang alasannya memberikan predikat kafir atas paham demikian (Ar-Raniri 139: 140).

Keenam adalah Murji'ah 'Ilmiyyah. Ar-Raniri mengatakan aliran ini meyakini "... Bahwa iman itu berbuat amal juwa tiada 'ilmu. Maka barang 
siapa tiada mengerjakan 'amar dan nahi munkan maka yaitu kafir. " Dikatakan paham demikian adalah kufur. Alasannya paham demikian mengingkari kesaksian dalam kalimat syahadat.

Ketujuh adalah Murji'ah Manqusiyyah. Ar-Raniri mengatakan aliran ini meyakini iman berkurang tiap-tiap tahun, tidak bertambah. Dikatakan paham demikian adalah kufur. Alasannya, QS. 9. 124 telah menyatakan bahwa yang percaya pada Allah dan pesuruhNya, maka bertambah iman mereka (Ar-Raniri, 2011: 140).

Kedelapan adalah Murji'ah Muntasyiyyah. Ar-Raniri mengatakan aliran ini meyakini "Aku mukmin jika dikehendaki Allah." Dikatakan paham demikian bila dia ragu pada imannya, maka menjadi kafir. Namun bila maksudnya dia dengan izin Allah menjadi mukmin, maka harus mengatakan Insya' Allah aku dalam Imu Allah mukmin. dikatakan juga aliran ini metakini tiada harus air sembahyang (untuk sembahyang). Paham demikian dikatakan kufur. Alasannya, QS: 5: 6 telah memerintahkan untuk membasuh muka, tangan hingga siku, menyapu kepala dan membasuk kaki hingga mata kaki (Ar-Raniri, 2011: 141).

Kesembilan adalah Murji'ah Asyarsyiyyah Ar-Raniri mengatakan aliran ini meyakini nabi adalah dalil (bukti kebenaran) Allah, sementara Alquran bukan dalil dan tidak memberi petunjuk. Dikatakan paham demikian adalah kufur. Alasannya, QS. 2: 2 telah menyatakan bahwa Alquran adalah petunjuk bagi yang takut pada Allah (Ar-Raniri, 2011: 142).

Kesepuluh adalah Murji'ah Bid'iyyah. Ar-Raniri mengatakan aliran ini meyakini manusia harus mengikuti setan, sekalipun setan itu menyuruh makan haram. Dikatakan paham demikian adalah kufur. Alasannya, QS. 168: 208 telah melarang mengikuti setan karena ia adalah seteru yang amat besar (Ar-Raniri, 2011: 143).

Kesebelas adalah Murji'ah Mutasyabbihiyyah Ar-Raniri mengatakan aliran ini meyakini Allah serupa dengan Nabi Adam. Mereka bersandar pada Hadits Bukhari dan Hadits Muslim yang menyatakan bahwa Adam dijadikan dari rupa Allah. Dikatakan paham demikian adalah kufur. Alasannya, QS. 42: 11 telah menyatakan bahwa tidak ada yang seripa dengan Allah (Ar-Raniri, 2011: 143).

Keduabelas adalah Murji'ah Hasywiyyah Ar-Raniri mengatakan aliran ini meyakini wajib dan sunat adalah sama karena sama-sama titah Allah. dikatakan juga aliran ini meyakini Allah tidak melihat dan tidak mendengar. Dikatakan paham demikian adalah kufur. Alasannya, QS. 22: 75 telah menyatakan bahwa Allah amat melihat dan amat mendengar. ArRaniri menegaskan golongan ini dikutuk oleh semua nabi Allah. katanya 
Sunan Turmudhi telah menerangkan bahwa Murji'ah dan Kadariah tiada menguntungkan bagi agama Islam (Ar-Raniri, 2011: 144-145).

\section{Karramiyyah}

Sebagaimana kaum Ahlus-sunnah Waljama'ah lainnya, Ar-Raniri meyakini terdapat tujuh puluh dua aliran dalam Islam. Semuanya diyakini sesat kecuali Ahlus-sunnah Waljama'ah. Adapun Karramiyyah, Muqta'iyyah dan Salimiyyah dikatakan termasuk golongan yang sesat.

Adapun keyakinan Karramiyyah adalah, 'Arsy adalah tempat Allah dan Kursiy adalah tempat berdirinya. Mereka juga dikatakan meyakini orang meninggal bukan karena dicabut nyawa oleh malaikat Izrail. Mereka juga dikatakan meyakini tempat Mi'raj Nabi Muhammad adalah dari perak, emas, yaqut dan marjan. mereka juga dikatakan meyakini waliullah lebih mulia daripada nabi dan meyakini Alquran adalah makhluk. Ar-Raniri mengataka segala keyakinan demikian adalah kufur dan sesat (Ar-Raniri, 2011: 147).

Sementara Muqta'iyyah dan Salimiyyah dikatakan meyakini Allah telah mengetahui sejak azali sebelum objek pengetahuan itu diadakan. ArRaniri mengatakan paham demikian adalah salah, karena sama dengan meyakini ketiadaan itu ada. Paham demikian menurutnya meyakini 'Ayan Tsabitah itu berwujud.

\section{Mulhid yang Bersufi-Sufi Dirinya}

-Raniri menyatakan di antara aliran-aliran yang sesat dalam Islam adalah semua mulhid, yakni mereka yang bersufi-sufi dirinya. Merujuk kepada Imam Al-Ghazali, Syaikh Abu Al-Najib Suhrawardi, Imam Najmuddin 'Umar Nasafi dan para teolog lainnya, Ar-Raniri membahas paham-paham sufi sesat dimaksud. Menurutnya golongan tersebut setidaknya ada tiga belas. Dikatakan mereka itu tidak pantas disebut sebagai sufi, tetapi kafir atau fasik (Ar-Raniri, 2011: 149).

Pertama adalah golongan Hubbiyyah. Ar-Raniri mengatakan mereka meyakini apabila seseorang telah mencapai martabat kasih Haqq Ta'ala, maka gugur baginya segala hukum dan keharusan beribadah. Dan segala yang haram menjadi halal baginya. Segala fardu baginya boleh dikerjakan, boleh tidak. Sebagian mereka dikatakan meyakini tidak harus menutup aurat. Juga bila telah mencapai derajat kesudahan kasih akan Allah, maka kalaupun melakukan dosa besar seperti zina dan mencuri, tidak akan dimasukkan ke dalam neraka. Bagi mereka halal perempuan orang. Dikatakan mereka juga meyakini telah gugur perintah dan gugur larangan, bagi mereka gugur segala ibadat zahir, melainkan cukup berpikir saja akan ibadat itu. Dikatakan mereka juga meyakini segala harta dunia 
adalah warisan dari Adam dan Hawa, sehingga boleh dipergunakan. ArRaniri memperingatkan agar memelihara para penempuh jalan sufi (pesuluk) agar terjauh dari paham-paham yang telah disebutkan (Ar-Raniri, 2011: 150-152).

Kedua adalah Awliyaiyyah. Ar-Raniri menyebuktan mereka meyakini bila telah mencapai derajat wilayah, yakni derajat waliullah, maka gugur bagi mereka perintah dan larangan. Dikatakan mereka juga meyakini derajat waliullah lebih utama daripada kenabian.

Ketiga adalah Sumrakhiyyah. Ar-Raniri mengatakan mereka meyakini bila hamba mengasihi Haqq Ta'ala, maka gugur baginya perintah dan larangan. Mereka mewajibkan bernyanyi, memukul rebana, berbagsi (berseruling), menari, berkecapi. Mereka dikatakan mengharuskan zina karena menilai perempuan seperti bunga yang harus dicium. Dikatakan aliran ini berasal dari Abdullah Sumrakiyyah. Ar-Raniri mengatakan mereka harus dibunuh (Ar-Raniri, 2011: 153-154).

Keempat adalah Ibahiyyah. Ar-Raniri mengatakan mereka meninggalkan kebaikan dan tidak menjauhi larangan; bila diri tidak sanggup melakukan kebaikan dan meninggalkan larangan, jangan menyeru orang untuk itu. Dikatakan mereka mengharuskan mengambil hak orang lain, berzina. Mereka dikatakan adalah seburuk-buruk makhluk .

Kelima adalah Haliyyah. Ar-Raniri mengatakan aliran ini meyakini harus menyanyi dan tepuk tangan hingga pingsan. Murud-murid aliran itu dikatakan meyakini syaikh mereka adalah orang yang memperoleh derajat tasawuf tanpa usaha. Dikatakan ajaran itu sesat dan tidak diajarkan Nabi Muhammad (Ar-Raniri, 2011: 155).

Keenam adalah Hurriyyah. Ar-Raniri mengatakan mereka meyakini apabila telah pingsan, datang bidadari dan mereka menyetubuhinya. Maka mereka mandi besar setelah tersadar. Tidak disebutkan predikasi khusus untuk ajaran ini. Dari narasinya, pedikasi untuk aliran ini disamakan dengan predikasi bagi aliran Ibahiyyah yakni seburuk-buruk makhluk dan predikasi bagi Haliyyah yakni sesat (ArRaniri, 2011: 156).

Ketujuh adalah Waqifiyyah. Ar-Raniri mengatakan mereka meyakini Haqq Ta'ala tiada dapat dikenal dengan sebenar-benar pengenalan. Mereka membunyikan syair Persia: "Thawathudani wa laysa maratu nadakas/ Turadu nadamar taratu mani bas." Yang artinya: "Engkau juwa hanya mengenal dirimu/ Tiada mengenal Dikau seorang juwapun." Dikatakan syair demikian adalah sesat (Ar-Raniri, 2011: 156157).

Kedelapan adalah Mutajahiliyyah. Ar-Raniri menatakan iktikad mereka adalah fasik karena mereka bersikap riya'. 
Kesembilan adalah Mutakasiliyyah. Ar-Raniri mengatakan mereka meninggalkan usaha dan pergi meminta-minta ke kedai-kedai dan rumahrumah, mengambil zakat dan sedekah, untuk mengisi perut. Paham demikian dikatakan bersalahan dengan jalan Nabi Muhammad (Ar-Raniri, 2011: 157).

Kesepuluh adalah Ilhamiyyah dari kaum Qirmitiyyah. Atau Ma'an. Mereka berpaham seperti Dahriyyah. Ar-Raniri mengatakan mereka meyakini Alquran adalah hijab kepada Haqq Ta'ala (Ar-Raniri, 2011: 125). Mereka hanya mengikut perkataan ulama dan syair hukama. Mereka juga disebut sesat.

Kesebelas adalah Hululiyyah. Ar-Raniri mengatakan mereka mengharuskan memandang pada perempuan cantik karena mereka itu adalah manifestasi keindahan Tuhan. Maka mereka harus mencium dan mendekap perempuan cantik. Mereka juga dikatakan menari-nari dalam bersuluk (Ar-Raniri, 2011: 158-159). Ar-Raniri (159) mengitip Syaikh Abu An-Najib Suhrawardi dalam Awarif Al-Ma'arif yang meneragkan sebagian dari kaum Hululiyyah menyerukan semua pekerjaan menyucikan hati dari hawa nafsu, serta yang mengerjakan syariat hanyalah bagi masyarakat awam.

Ar-Raniri juga mengatakan sebagian golongan Hululiyyah meyakini Haqq Ta'ala masuk ke dalam jasad mereka. Paham demikian dianggap sama dengan paham Nasrani yang menganggap Haqq' Ta'ala masuk ke jasad Nabi Isa (Ar-Raniri, 2011: 160).

Dikatakan juga sebagian Hululiyyah adalah Halajiyyah. Disebutkan mereka meyakini sebagaimana keyakinan Al-Hallaj yaitu mengatakan 'Saya adalah Al-Haqq"; dan seperti Syaikh Abu Yazid Al-Bistami yang mengatakan "Maha suci aku, alangkah agungnya aku". Seharusnya, kata Ar-Raniri, kedua orang itu hanya menyematkan pedikat-predikat agung itu hanya kepada Allah.

Keduabelas adalah Wujudiyyah dan Ittihadiyyah. Disebut juga mereka mulhid dan zanadiqah. Ar-Raniri mengatakan mereka memaknai 'La Ilaha illa Allah' dengan: wujudku itu adalah wujud Allah. Mereka dikatakan berpaham wujud Allah tiada kecuali wujudnya itu adalah wujud makhluk. Dikatakan mereka menyifatkan wujud Allah pada wujud makhluk yang banyak. Mereka disebutkan meyakini tiada maujud kecuali Allah (Ar-Raniri, 2011: 161-162).

Sekalipun memahami diskursus differensiasi antara Wajib alWujûd yang dinisbahkan pada Haqq Taala dan mumkin al-wujûd yang dinisbahkan pada makhluk-makhluk, Ar-Raniri tidak dapat menerima argumentasi tesebut (Ar-Raniri, 2011: 163-165). Dia keberatan pada pernyataan Wahdatul Wujud yang mengatakan "Laysa fi darr al-wujud 
ghayr dayyar', yaitu tiada pada wujud selain Dia. Ar-Raniri melihat ini sebagai kekejian dan kesalahan karena paham teologis menerima setiap mawjudat yakni maujud-maujud yang beragam masing-masing memiliki eksistensi mandiri. Sebagaimana keyakinan umum teolog, Ar-Raniri meyakini wujud bermakna ekuivokal, yaitu satu kata yang memiliki pluralitas acuan (misydaq).

Ar-Raniri mendasarkan pandangannya pada Imam Al-Ghazali yang mengatakan segala maujud-maujud yang beragam itu baharu. Mereka dijadikan oleh Haqq Ta'ala. Ar-Raniri melihat pandangan Wahdatul Wujud berkonsekuensi pada penerimaan yang baharu sebagai Haqq Ta'ala juga dan Haqq Ta'ala berkonsekuensi menjadi majemuk. Maka antara lain atas alasan itulah dia mengatakan paham Wahdatul Wujud adalah sesat (ArRaniri, 2011: 165).

\section{Ahlul Wahdah}

Ar-Raniri mengatakan Ahlul Wahdah itu ada dua. Pertama adalah yang meyakini wujud hanya satu yakni wujud Allah. Sementara selainnya tiada wujud dan jadinyapun tiada dapat. Sehigga dalam pandandangan golongan ini, menurut Ar-Raniri, segala wujud dianggap Wujud Allah. Menurut Ar-Raniri, inliah pandangan Wujudiyah yang dianggapnya sesat (Ar-Raniri, 2011: 166). Kedua, Ahlul Wahdah yang meyakini wujud terbagi dua, yaitu Wujud Haqiqi yang dinisbahkan pada Haqq Ta'ala dan wujud khayali yang dinisbahkan pada makhluk-makhluk. "Haqq Ta'ala," kata ArRaniri, menurut Ahlul Wahdah golongan kedua ini, "adalah maujud yang tiada kelihatan, tetapi tiada bagi-Nya wujud Maka jumlah sekalian alam itu wujudnya umpama rupa khayal yang kelihatan dalam cermin. Tiada baginya pada hakikatnya, melainkan wujud khayal juwa atau umpama bayang-bayang juwa" (Ar-Raniri, 2011: 167). Golongan ini dianggap sebagai golongan yang benar yang disebut dengan Ahlullah.

\section{Bahas Iktikad Hamzah Fansuri}

Ar-Raniri (mengatakan, Hamzah Fansuri dalam kitab Al-Muntabi meyakini makna hadits qudsi: siapa kenal diri, maka telah kenal Rabbnya, bahwa dirinya dan sekalian alam dalam ilmu Allah, seperti sekalian bagian pohon telah lengkap dalam biji. Maka keluarlah alam dari ilmu Allah seperti keluarnya batang, daun dan buah dari biji. Dikatakan paham demikian adalah kufur (Ar-Raniri, 2011: 168-169).

Ar-Raniri mengatakan, Hamzah Fansiru melarang menyifatkan melihat Haqq Ta'ala seperti kain basah dan air karena air dan kain berbeda. Tetapi harus seperti lain dan ombak. Karena laut adalah satu 
dengan ombak sehingga makhluk dengan Allah satu, maka paham demikian dianggap kufur (Ar-Raniri, 2011: 169-170).

Ar-Raniri mengatakan Hamzah Fansuri juga mengatakan matahari, cahaya matahari dan panas matahari, meski nama dan rupanya tiga, tetapi hakikatnya satu. Ar-Raniri mengatakan paham demikian seperti paham Nasrani yang meyakini wujud Bapa, wujud Anak dan dan wujud Ibu adalah tiga nama yang hakikatnya satu wujud. katanya paham demikian adalah kekufuran sebagaimana paham falasifah (Ar-Raniri, 2011: 170).

Ar-Raniri mengatakan, dalam paham Hamzah Fansuri, "Siapa kenal dirinya.." bukan mengenal jantung, paru-paru, kaki atau tangan, bermakna wujud makhluk dan wujud Tuhan adalah esa. Bagi Ar-Raniri perkataan demikian adalah perkataan kafir (Ar-Raniri, 2011: 170-171).

Ar-Raniri juga menyatakan Hamzah Fansuri mengatakan keadaan makhluk bermula dengan keadaan Tuhan dan melihat Tuhan dengan penglihatanNya. Dikatakan paham demikian adalah kufur karena menjadikan wujud dan sifat makhluk yang baharu bersatu dengan wujud dan sifat Tuhan yang kadim.

Ar-Raniri juga mengatakan Hamzah Fansuri meyakini QS. 55: 29 pada zahir majemuk dan berubah-ubah karena QS. 57: 3 Awwal tiada ketahuan, Akhir tiada Kesudahan; Batin tiada terjangkau, pada zat, sifat, perbuatan, dan jejek (athar), yang mana empat nama itu hakikatnya adalah satu. Menurut Ar-Raniri paham demikian adalah kufur. Alasannya karena dijadikannya makhluk dan Khalik bersuatu. Dikatakan juga Hamzah Fansuri mengatakan "pada zahirnya wujud makhluk, tetapi pada hakikatnya Allah." Maka Ar-Raniri mengatakan paham demikian adalah paham Ittihad.

Ar-Raniri juga mengatakan, Hamzah Fansuri meyakini, pada hakikatnya Zahir dengan mazhar tiada bercerai. Dikatakan juga Hamzah Fansuri meyakini pertama ilmu adalah makrifat akan Allah. "Adapun kesudahan-sudahan makrifat itu tatkala datanglah kepada had faqir bahwa ialah Allah." Maksud Ar-Raniri (173), paham penganalogian makhluk dengan Haqq dengan bertiup angin ombak timbul, berhenti angin, ombak kembali, adalah kufur, karena kesalahannya telah nyata (Ar-Raniri, 2011: 172).

Ar-Raniri juga mengecam keyakinan yang menganalogikan Khaliq seperti biji dengan pohon kayu di dalamnya. Disimpukan paham demikian meyakini dua zahir kelihatan, namun hakiatnya satu. Paham demikian disamakan Ar-Raniri dengan paham Mansur Al-Hallaj yang menyatakan zatnya tiada dilihat lagi, kefakiran adalah tiada suatu juapun baginya. Juga dikatakan Hamzah Fansuri menyerukan "jika tiada menerima kufur, maka 
tiada bertemu dengan kufur." Paham demikian dikatakan sebagai paham zindik yang menyebabkan kekufuran (Ar-Raniri, 2011: 174).

\section{Bahasa Syamsuddin As-Sumatrani}

Ar-Raniri mengatakan ajaran Syamsuddin As-Sumatrani dalam Mir'ah Al-Mubaqqiqin yang menyatakan pri nisbah artinya perbangsa makhluk dengan Haqq Ta'ala adalah kekufuran yang sama dengan Hamzah Fansuri. Hal itu diyakini melanggar QS. 112: 4 yang menyatakan tiada apapun yang sebangsa dengan Haqq Ta'ala. Juga disebutkan Syam menyamakan Haqq Ta'ala dengan makhluk merujuk pada pemaknaan keliru atas QS. 57: 4 yang mengatakan Allah bersama makhluk dimanapun dia berada dan QS. 2: 115 yang menyatakan ke manapun wajah dihadapkan, ada Allah. Juga dikatakan Syamsuddin As-Sumatrani menyalah artikan QS. 4: 126 yang menyatakan Allah meliputi sekalian alam (Ar-Raniri, 2011: 175).

Menurut Ar-Raniri As-Sumatrani meyakini wujud makhluk adalah wujud Allah dengan mengajukan hadits qudsi yang menyatakan "Tiada wujud dalam wujud ini melainkan aku juwa.". Dikatakan hadits qudsi: "Aku rahasia manusia yang mendiamkan dia, datang menggerakkan dia," bermakna insan itulah Allah (Ar-Raniri, 2011: 177-178). Hadits qudsi berbunyi "Hajar Aswad itu tangan kanan Allah di muka bumi" sebagai keyakinan batu itu adalah anggota badan Allah. Hadits dalam Syarah Sunan Nasa'i berbunyi: "Ini tangan Allah dan ini tangan Usman," adalah keyakinan As-Sumatrani secara literal. Ayat-ayat mutasyabihat, yakni yang maknanya samar, kata Ar-Raniri dipakai As-Sumatrani untuk meyesatkan orang dengan menjual agama (Ar-Raniri, 2011: 179).

"Maha suci aku, maha besar pekerjaanku,", kata Bayazid Bistami; "Tiada dalam bajuku ini lain dari pada Allah Ta'ala," kata Syaikh Sabili; "Aku yang amat kuasa atas semesta alam," kata Abu Al-Ghayt; "Akulah yang sebenar-benarnya," kata Al-Hallaj; "Akulah Allah Allah Ta'ala," kata Nusaym, menurut Ar-Raniri ) diyakini oleh As-Sumatrani, kata-kata 'aku' tersebut merujuk kepada pengucap (Ar-Raniri, 2011: 181-183. Sementara bagi Ar-Raniri, ucapan-ucapat tesebut adalah syatahat yang merujuk maksud 'aku' adalah Allah sehingga ucapan para sufi tersebut tidak sesat menurut Ar-Raniri. Tetapi yang sesat adalah Syamsuddin As-Sumatrani yang dianggap memaknai kata 'aku' itu adalah para pengucap. Bagi ArRaniri, kesesataun adalah ketika menganggap wujud bayangan dengan pemilik bayangan adalah satu wujud. Sementara bila menganggap wujud yang nyata hanya wujud pemilik bayangan tetapi bayangan adalah kefanaan, maka paham demikian tidak sesat (Ar-Raniri, 2011: 183). 


\section{Bahas Allah Menjadikan Adam Rupa Dirinya}

Ar-Raniri mempersoalkan esai Hamzah Fansuri berjudul Khirqah. Di dalam tulisan tersebut, kata Ar-Raniri, disebutkan sebuah hadits Shahih Bukhari yang menyatakan Allah meciptakan Adam atas rupa-Nya. Disimpulkan Ar-Raniri diitikadkan Hamzah Fansuri dijadikan Adam atas Wujud Allah karena Wujud Allah, lalu dari wujud Adam, wujud anak cucu Adam dan wujud segala alam (Ar-Raniri, 2011: 185-186). Tetapi Ar-Raniri menginginkan wujud Allah dengan wujud makhluk dipisahkan. Analoginya, wujud pakaian dengan yang memakai pakaian harus dibedakan. Ar-Raniri mengecam syair Hamzah Fansuri: akan rupa adam itu jangan kau ghafil/ hikmah Tuhan di sana kami. Dimaknai Ar-Raniri syair itu mengitikadkan bahwa Adam adalah penampakan wujud Tuhan. Bagi Ar-Raniri, penampakan itu, yakin Adam, umpama pakaian. Sementara pencipta Adam diumpamakan pemakai pakaian, sehingga pakaian dengan yang memakai pakaian harus beda.

Kata Ar-Raniri, Hamzah Fansuri meyakini wujud Allah juga adalah wujud insan. Fansuri mengajukan Hadits Qudsi yang menyatakan insan adalah rahasia Allah dan Allah adalah rahasia insan. Dikutip juga pernyataan Hamzah Fansuri (bandingkan, Noer, 1995: 61-62): : "Pada martabat Ahadiyyah Haqiqi pada martabat manusia, bayannya zatnya. Yakni tatkala sekarang pada martabat insan Ahadiyyah Al-Jami' bayannya adalah manusia. Demi Allah jangan lagi syak. Tatlaka pada martabat Ahadiyyah haqiqi, insan batinnya; Ahadiyyah Haqiqi zabimya. Tatkala sekarang; Ahadiyyah al-Jami batinnya, insan zabirnya."

\section{Makna Hadis}

Bagi Ar-Raniri insan itu maujud dalam ilmu Haqq Ta'ala dan Haqq Ta'ala maujud dalam hati insan (Ar-Raniri, 2011: 118-119). Maksud insan adalah insan yang kamil, di dalam hatinya dia tiada lupa dan tiada lalai akan Haqq Ta'ala. Dengan itu juga insan yang arif tiada pernah dilupa dan dilalaikan oleh Haqq Ta'ala sebagaimana telah dinyatakan dalam QS. 20: 52 .

Dalam paham Ar-Raniri matahari di langit dan matahari di bumi adalah berbeda. Matahari di cermin tidak nyata. Bila matahari di cermin sama dengan matahari di langit, maka terbakarlah cermin. Baginya, paham Wujudiyah yang sesat itu menyamakan wujud Allah dengan wujud makhluk (Ar-Raniri, 2011: 190-191).

Bagi Ar-Raniri ajaran Wujudiyah yang menyerukan untuk menghilangkan eksistensi diri (akan diri kita pun jangan diingat lagi) adalah ajaran yang demikian dalam pandangan Nabi Muhammad adalah kekufuran (Ar-Raniri, 2011: 192-193). 
Ajaran-ajaran Wujudiyah yang dianggap sesat oleh Ar-Raniri diajarkan dalam buku-buku seperti Mir'ah Al-Muhaqqiqin atau Khirqah, Haqq Al-Yaqin, Dairah Al-Wujud, Sir Al-Rububiyyah, Kasyf AlRububiyya, Sirr Al-Anwar, semua kitab Hamzah Fansuri dan Syamsuddin As-Sumatrani dan banyak lainnya, dimintakan kepada penguasa untuk membakar buku-buku tersebut.

Kata Ar-Raniri, ajaran pengikut Wujudiyah seperti Jamaluddin dan sebagian lainnya, menyerukan untuk mengakui "bahwasanya tiada ada wujudku ini hanya sanya wujudku inilah wujud yang mutlak dan akulah yang memerintahkan sekalian alam". Dikatakan juga ajaran mereka memerintahkan agar meniatkan diri yang shalatlah yang maha besar saat bertakbir dalam shalat (Ar-Raniri, 2011: 194-195).

Ketigabelas adalah kaum Mutasyabbihah atau Musyabbihah dan Mujassimah yang artinya paham Tuhan mirip makhluk atau memiliki aksiden. kata Ar-Raniri paham ini meyakini Allah Ta'ala itu jawhar yang maujud dan sebagian dari mereka dikatakan meyakini Tuhan itu memiliki jism yaitu jasad, tetapi jasadnya tidak seperti jasad yang lain. Sebagian lain dari aliran ini dikatakan meyakini Allah Ta'ala seperti rupa insan dengan mengemukakan Hadits: Kulihat akan Tuhanku pada rupa yang muda balia. Sebagian lainnya dikatakan meyakini Allah Ta'ala memiki daging, darah, wajah dan rupa laksana manusia, berkaki, memiliki jari-jari, dengan merujuk Hadits: Adalah hati antara hamba itu dua dari pada jari Tuhannya yang bernama Rahman. Juga Hadits yang menyatakan neraka meminta tambahan penghuni ketika Tuhan menanyakan apakah ia sudah penuh dan Allah menghantarkan khadimnya ke dalam neraka. Ada juga golongan ini yang yakin kepada Haqq Ta'ala, tetapi rupanya tiada diketahui. Ada juga sebagian golongan ini dikatakan meyakini Allah Ta'ala gilang-gemilang. Juga bagian golongan ini dikatakan meyakini Allah datang dan turun dengan ZatNya serta bergerak dan berpindah dari satu tempat ke tempat lain. Sebagian lain dari golongan ini dikatakan meyakini Allah duduk di atas 'Arasy. Juga sebagian dari mereka dikatakan meyakini Allah hulul daripada 'Arasy. Maka dikatakan semua bagian dari golongan ini kufur. Alasannya QS. 42 telah menegaskan bahwa tidak ada papun yang serupa dengan Allah. Siapa yang meyakini Allah itu jism atau Dia hulul di dalam jism atau atau itihad denganNya, maka kata Ar-Raniri, selua ulama sepakat paham demikian adalah kafir (Ar-Raniri, 2011: 195).

Menurut Ar-Raniri segala nama anggota jasad itu maksud kepada Allah bukanlah jism tetapi sifat Allah. Bila meyakini sebagai jism, maka akan meniscayakan keberelasian Allah dengan yang lain. Dan menurutnya ini mustahil (Ar-Raniri, 2011: 199). Dikatakan Allah bukanlah sejenis dan 
tiada memiliki surah, sehingga mustahil Dia serupa dengan sesuatu. Allah bukan jenis (genus) dan bukan bagai (spesies).

\section{Soal-Soal}

Soal, apabila kita ditanyai orang: Bila Allah harus dikata syay, bukankah itu menyamakannya dengan makhluk? Ar-Raniri menjawab: Allah Ta'ala adalah syay yang Maujud yang Hakiki, tiada baginya segala rupa syay. Sementara alam adalah maujud baharu dan memiliki surah dan dan sejenis. Maka ia tiada sejenis dengan syay Haqq Ta'ala (Ar-Raniri, 2011: 204).

Soal, apabila kita ditanyai orang: Apa makna hadits Nabi Muhammad yang mengatakan Allah menciptakan Adam dari rupaNya atau rupa Rahman? Ar-Raniri menjawab: Rupa dimaksud hanya ibarat atau isyarat. Misalnya larangan Nabi Muhammad pada seorang majikan agar tidak memukul wajah sahayanya karena wajahnya itu adalah adalah citra Adam (Ar-Raniri, 2011: 205-206).

Soal, apabila ditanyai orang: Apa makna Hadits Nabi Muhammad: Kulihat rupa Tuhanku sebaik-baik rupa. Ar-Raniri menjawab: Bahwa maksud kalimat tersebut adalah kiasan. Misalnya, kiasan tersebut sering dipakai orang Arab kepada temannya yang berjalan kaki: kulihat engkau sedang berkendaraan, maksudnya adalah dia melihat temannya itu akan berkendaraan. Dan maksud melihat Tuhan adalah kelak melihatNya di surga (Ar-Raniri, 2011: 208-209).

Soal, apabila ditanyai orang: Apa makna Hadits yang mengatakan bahwa Tuhan menampakkan rupaNya (tajali) di Padang Mahsyar dalam rupa yang tidak dikenali dan rupa dikenali? Ar-Raniri menjawab: Makna kalimat tersebut adalah kiasan, seumpama kalimat: Apa rupa pekerjaan ini?, atau: Apa rupa perkara ini?. Maka rupa dimaksud bukan surah atau gambar tetapi sifat. Sehingga maksud rupa pada hadits tersebut berarti kelak di Padang Mahsyar sifat-sifat kepemurahan Tuhan akan dilihat manusia, baik yang dapat dipahami maupun tidak (Ar-Raniri, 2011: 210211).

\section{Bahas Bidah}

Ar-Raniri mengatakan, menurut Syaikh Ali bin Ahmad AlBahaimi, bidah terbagi lima bagian. Pertama dalah bidah wajib seperti menafsirkan Alquran, mansyarah hadits, mengarang ilmu alat seperti ilmu lughah, ilmu nahwu, ilmu bayan dan 'arud (sastra), ilmu faraid, ilmu ushuluddin, ilmu ushul fiqih dan ilmu hadits. Kedua bidah sunat seperti mendirikan madrasah dan menguraikan masalah-masalah besar dalam tasawuf. Ketiga adalah bidah yang mubah, seperti bejabat tangan setelah 
shalat Subuh dan Ashar, makan makana lezat, memakai pakaian yang baik, mendiami rumah yang baik dan meluaskan kain lengan baju. Keempat bidah yang haram yaitu seperti aliran Qadariyyyah, Murji'ah, Mujassimah dan Wujudiyyah (Ar-Raniri, 2011: 213).

Kata Ar-Raniri, Syaikh Abu Syakur Salimi dalam Tambid, bahwa bidah itu ada lima perkara. Yaitu bidah kepada Zat Allah, bidah kepada kalam Allah, bidah kepada perbuatan Allah, bidah kepada segala perbuatan hamba Allah, dan semua sahabat Nabi Muhammad. Bidah pada Zat, sifat dan perbuatan Allah, kata Ar-Raniri, sepakat semua ulama, itu digolongkan pada kekafiran. Bila bidah pada perbuatan hamba Allah dan sahabat Nabi Muhammad bertentangan dengan Alquran dan Hadits maka tetap dianggap kufur. Namun bila bertentangan dengan qiyas atau hadits yang tidak sahih dan hadits takwil atau samar maknanya, maka itu dianggap bidah tercela. Dan dianjurkan pada pelaku bidah tersebut untuk bertaubat (Ar-Raniri, 2011: 215-216).

Para pelaku bidah dianjurkan untuk diperarangi hingga mereka kembali pada itikad yang dianggap tidak bertentangan dengan yang diinginkan.. Namun bila tidak mau bertaubat, harus dibunuh. Bila mau bertaubat, diterima taubat mereka. Dengan berlandaskan pada Hadits Sahih Bukhari, kata Ar-Raniri, sebagian ulama berkeyakikan, golongan Ibadiyyah, Ghabiyyah, dan sebagian Rafidi dan sebagian Qaramitah harus dibunuh dan bunuh itu adalah bagian dari penerimaan taubat mereka (ArRaniri, 2011: 217).

\section{Taifah Sufi yang Aahlullah}

Sufi Ahlullah menurut Ar-Raniri adalah mereka yang mengikuti Nabi Muhammad, mengerjakan fardu, menjauhkan diri dari bernyanyi, menari dan segala perbuatan kaum sufi yang dianggap sesat. Mereka menunaikan hak orang lain, menjauhkan diri dari yang haram, membahagiakan semua makhluk Allah dan tiada berbantah-bantah dengan semua orang Islam. Bila dibantah orang, mereka diam, tidak mengumpatupat. Mereka tidak menghendaki penghiasan dan kebesaran di dalam dunia. Jalan mereka adalah jalan semua orang saleh, tabi', tabi'in dan sahabat Nabi Muhammad. Merekalah yang digolongkan sebagai Ahlussunnah Waljama'ah. Dikatakan bila mengasihi mereka, seakan mengasihi Allah dan Nabi Muhammad (Ar-Raniri, 2011: 218).

Ar-Raniri menganjurkan agar memuliakan dan bersahabat dengan sufi-sufi yang dia golongkan tidak sesat. Dikatakan bila meghinakan pelaku bidah, maka akan disentosakan Allah. Tapi bila memuliakan mereka, maka termasuk peruntuh agama. Kata Ar-Raniri, pelaku bidah itu adalah sehinahina manusia. Dikatakan mereka lebih hina daripada hewan. Alasannya 
karena segala yang baru dalam agama adalah tertolak. Dan yang mengadakan yang baru dalam agama akan dilaknat Allah (Ar-Raniri, 2011: 220-221).

\section{KESIMPULAN}

SebelumAr-Raniry ke Aceh Darussalam, pola keberagamaan masyarakat Aceh sangat beragam (Said, tt: 89-90). Kedatangan Ar-Raniry bertujuan untuk mensingularitaskan sebuah aliran dengan menuduh aliranaliran lain sebagai ajaran sesat. Kitab-kitab yang dianggapnya tidak sesuai dengan ajaran yang dia anut diperintahkan untuk di bakar (Al-Attas, 1975). Para pengikut ajaran yang tidak sesuai dengan keinginan Ar-Raniry diperintahkan untuk mengikut kepada aliran yang dia anut, bila tidak, maka dia memerintahkan orang untuk membunuh mereka.

Hasrat Ar-Raniry sangat didukung oleh penguasa waktu itu yakni Iskandar Tsani. Raja itu adalah orang dari Pahang yang datang menkahi putri Iskandar Muda. Setelah Iskandar Muda wafat, maka kekuasaan jatuh ketangannya. Raja baru itu dengan mudah mengikuti nasehat Ar-Raniry. Dia tidak mempertimbangkan kondisi sosio kultural Aceh dalam membuat kebijakan. Di samping itu juga Ar-Raniry adalah ulama yang beresal dari India yang dapat ke Aceh lalu menuduh ajaran-ajaran yang tidak sesuai dengan kehendaknya sebagai ajaran sesat. Dia menetapkan fatwa tanpa memahami secara detail ajaran dan kondisi yang berlaku. Dia terkesan hanya mengaktualisasikan teks teologi ke dalam kehidupan nyata.

Kitab 'Tibyan fi Ma'rifah Al-Adyan' yang ditulis Ar-Raniry dapat disebut sebagai sebuah buku panduang pengkafiran. Karena di daamnya berisi klaim-klaim sesat terhadap semua ajaran kecuali Ahlus-sunnah Waljama'ah. 


\section{DAFTAR PUSTAKA}

Al-Attas, Syed Muhammad Naquib, A Commentary on the Hujjat Al-Sbiddiq of Nûr Al-Din Al-Ranirî, Kuala Lumpur: Kuala Lumpu, 1986.

Al-Attas, Syed Muhammad Naquib, Commens on The Re-Examination of AlRanirî 'sHujjat Al-Shiddiq: Revitation, Kuala Lumpu: Muzium Negara, 1975.

Al-Attas, Syed Muhammad Naquib, Raniri and the Wujudiyah of $17^{\text {th }}$ Century Acheh, Singapore: MBRAS, 1966.

Al-Attas, Syed Muhammad Naquib, The Mysticism of Hamzah Fansûrî, Kuala Lumpur: University of Malaya Press, 1970.

Ar-Raniri, Syaikh Nuruddin, Al-Tibyan fi Ma'rifah Al-Adyan, Banda Aceh: Pena, 2011

Azra, Azyumardi, Islam Nuzantara: Jaringan Global dan Lokal, Bandung: Mizan, 2002.

Azra, Azyumardi, Jaringan Ulama: Timur Tengah dan Kepulauan Nusantara Abad XVII \& XVIII, Jakarta: Kencana, 2013.

Azra, Azyumardi,, Hamzah Fansuri dan Pemikiran Wabdatut Al-Wujud dalam Asrar Al-'Arifin, Jakarta: Tesis ICAS-Paramadina, 2014

Fathurahman, Oman, Tanbih Al-Masyi: Menyoal Wabdatul Wujud: Kasus Abdurrauf Singkel Di Aceh Abad 17, Bandung: EFEO \& Mizan, 1999.

Hasjmy, A. Ruba’i Hamzah Fansuri, Kuala Lumpur: Dewan Bahasa dan Pustaka, 1976.

Miswari, Filsafat Terakhir, Lhokseumawe: Unimal Press, 2016

Miswari, Wujud dalam Asrar Al-Arifin: Pembuktian Wabdat Al-Wujud Hamzah Fansuri, Tesis, ICAS_PAramadina Jakarta, 2014.

Nasution, Harun, Mubammad Abduh dan Teoogi Rasional Mu'tazilah, Jakarta: UI Press, 2006 
Nasution, Ismail Fahmi Arrauf and Miswari, "Rekonstruksi Identitas Konflik Kesultanan Peureulak". Paramita: Historical Studies Journal, Vo. 27, No. 2, (2017).

Said, Mohammad, Aceh Sepanjang Abad, Vol. 1, Medan: Waspada, Tt. 